\title{
RESOLUÇÕES DO CONGRESSO DA CONLUTAS (2012)
}

\section{Tema 1 - Conjuntura Internacional e Nacional}

\section{Internacional}

A crise econômica mundial, a maior desde o "crash de 1929", tem causado enormes abalos nos mercados de todo o mundo e nos governos da Europa e dos EUA. A atual crise econômica internacional é continuidade da crise iniciada em 2008, combinada com uma crise do sistema financeiro mundial e que atinge agora um novo pico com uma paralisia do sistema de crédito.

Se inicialmente o epicentro da crise estava nos EUA, neste momento é a zona do euro o pólo imperialista mais afetado. A crise econômica internacional afetou o conjunto da economia européia, diminuindo os ingressos de euros dos países mais frágeis e gerando uma crise de dívidas públicas e uma segunda crise do euro. Os estados europeus sobre endividaram-se, seja para ajudar diretamente os bancos, seja para garantir o pagamento de dívidas públicas que cresciam aceleradamente a cada refinanciamento, devido a taxas de juros extorsivos, determinados pela "classificação" desses países feita por agentes dos próprios banqueiros. Grécia e Irlanda foram os primeiros exemplos de um processo que abarca toda a zona do euro e arrasta neste momento economias de países como Portugal, Espanha e Itália.

Para preservar o euro, já que sua explosão seria uma "catástrofe" para a economia burguesa e as finanças mundiais, o imperialismo, especialmente, o alemão e o francês, exige a submissão desses países aos planos de austeridade econômica estabelecidos pela troika (Banco Central Europeu, União Européia e FMI). Os governos de plantão, muitas vezes indicados pelos banqueiros, em completo desrespeito às constituições locais, representam a perda de soberania nacional, 
ao mesmo tempo potencializando uma verdadeira "guerra social" aos trabalhadores e a juventude. Assim, para salvar o capital sacrificam-se, de forma selvagem e sem mediações, condições de vida, conquistas sociais e direitos dos trabalha- dores. Cortes de salários e aposentadorias, drásticas reduções no orçamento dos serviços públicos essenciais, privatização de estatais, fim das negociações coletivas e de direitos trabalhistas para facilitar demissões, são algumas das medidas impostas para destinar mais dinheiro para o pagamento das dívidas. Estas medidas impostas pela burguesia representam o fim do chamado "Estado de Bem Estar Social".

O sistema capitalista imperialista já não pode mais garantir a manutenção de nenhuma dessas conquistas e necessita destruí-las para defender a sua taxa de acumulação e seus lucros, descarregando, como de costume, o custo da crise por eles criada nas costas dos trabalhadores e do povo.

Tudo isso tem provocado uma profunda instabilidade política e social no velho continente e produzido uma situação explosiva como pode se verificar na crescente resistência das massas aos planos de ajustes desde as greves gerais na Grécia, Portugal e Inglaterra, à marcha dos indignados na Espanha e nas derrotas eleitorais dos partidos governistas como, por exemplo, a ocorrida, recentemente, na Espanha e na França.

A economia dos EUA, origem da crise mundial, vive uma conjuntura diferente, com um pequeno crescimento econômico. Isso se dá em base a um ataque brutal de Obama, o presidente negro, contra o proletariado norte-americano, com reduções salariais para garantir o salvamento de grandes empresas, como a GM. O povo negro norte-americano sofre duramente com os ataques de Obama. Há um início de um processo de luta, que começou com o Occupy Wall Street, se estendendo a dezenas de cidades e algumas greves importantes no coração do imperialismo.

A crise do imperialismo se agravou com o enorme e vitorioso processo de revoltas populares que se alastrou pelo do Norte da África e Oriente Médio e varreu ditaduras sanguinárias há décadas no poder. $\mathrm{A}$ 
derrubada do ditador Ben Ali da Tunísia, há mais de um ano, foi o estopim de um processo que se alastrou pelo mundo árabe, abriu uma crise na dominação imperialista nessa região estratégica pelas reservas de petróleo e animou novos movimentos em todo o mundo. A revolta das massas árabes contra anos de exploração, miséria e desemprego, agravados pela crise econômica mundial, não poupou governos títeres sustentados por décadas pelo imperialismo americano e europeu como Mubarak no Egito e Kadafi na Líbia, em que se desmascarou o caráter pró-imperialista de seus regimes nos últimos vinte anos.

A fim de manter seu domínio na região e deter a ação das massas, o imperialismo apoiou a criação de um governo de "transição" no Egito formado por uma Junta Militar. Na Líbia, além de intervir militarmente, procura através do Conselho Nacional de Transição (CNT), retomar o controle do país. No lêmen, para pacificar as massas, o governo norte americano costurou acordo com a Arábia Saudita, que obrigou o dita- dor Ali Abdullah Saleh a renunciar. Porém, na medida em que esses novos governos não atendem às necessidades fundamentais do povo, rapidamente as massas perdem as ilusões, tomam consciência da trapaça e retomam as mobilizações: reacendem-se as manifestações na Praça Tahir no Cairo e segue a luta do povo sírio pela derrubada da ditadura de Assad.

Somente a luta popular organizada poderá tornar a classe trabalhadora sujeito de seu destino e dos rumos da História. O exemplo dos povos árabes na luta contra o governo de transição no Egito e a luta contra o CNT na Líbia animam mobilizações mundo afora, como do "15-O", a heroica luta dos estudantes chilenos e dos indígenas bolivianos.

A China entrou em uma combinação de desaceleração econômica e um grande ascenso sindical. O proletariado chinês começou a colocar-se em movimento, protagonizando uma grande leva de greves contra o padrão salarial aplicado pela ditadura capitalista imposta pelo PC (Partido Comunista). A combinação de desaceleração econômica, greves salariais e lutas democráticas podem levar a um questionamento ao que é apresentado como um dos modelos do capitalismo moderno. 
A América Latina foi inundada por dólares nos últimos anos pelos preços recordes das matérias-primas que exporta e pelos fluxos dos investidores, que trouxeram bilhões - a maior parte especulativa para a região, atraídos pelo modesto crescimento econômico e pelas altas taxas de lucro, muito maiores que as do mundo desenvolvido. No entanto, o crescimento não é suficiente para afastar o fantasma da crise econômica mundial e as consequências sobre os trabaIhadores e o povo pobre. Agora, o impacto da crise europeia e a desaceleração da economia chinesa começam a se manifestar na redução do crescimento econômico na América Latina.

A crise da empresa petrolífera YPF na Argentina, que foi nacionalizada em $51 \%$ pelo governo Kirchner, é parte dessa nova realidade. Essa empresa, desde sua privatização pelo governo peronista de Menen, saqueava a Argentina, extraindo o petróleo e o gás, mas reduzindo os investimentos no país e aumentando a remessa de lucros. Houve uma queda na produção e nas reservas, levando a que, pela primeira vez na Argentina tenha ocorrido um déficit comercial em combustíveis de três bilhões de dólares. Nós defendemos a nacionalização da YPF contra os ataques do governo imperialista espanhol, mas exigimos sua nacionalização em 100\%, sob o controle dos trabalhadores.

A luta dos povos latino-americanos e o sentimento anti-imperialista levaram ao enfraquecimento dos EUA na região e a ascensão de diversos governos de frente popular na América Latina. Infelizmente, esses governos, ao assumirem, esqueceram a luta pela soberania e a libertação do imperialismo, colocando em prática as mesmas políticas de contratação dos gastos públicos com os serviços essenciais, a retirada de direitos trabalhistas e a criminalização de movimentos sociais.

A crescente militarização da região e a criminalização dos movimentos sociais e da pobreza perpetradas pelos governos estão a serviço de tentar conter as lutas e as mobilizações dos trabalhadores e da juventude por melhores condições de vida e trabalho, que o capitalismo não tem nem condições, nem a perspectiva de garantir. A brutal repressão aos indígenas bolivianos, à luta dos estudantes chilenos e a vergonhosa ocupação militar do Haiti, composta por forças latino-americanas, são exemplos claros desta política. 
Por tudo isso, o $1^{\circ}$ Congresso da CSP-Conlutas saúda as revoltas populares do Norte da África e Oriente Médio e apoia as lutas dos trabalhadores e da juventude da Europa e de todo o mundo na certeza de que é preciso lutar, pois é necessário e possível vencer!

O capital e os governos de turno não têm como atender às necessidades e os interesses dos trabalhadores e da juventude. Só a luta dos trabalhadores e da juventude de todo o mundo pode construir uma alternativa operária e socialista que garanta emprego, saúde, moradia, educação e transporte para todos em um mundo sem exploração e opressão.

O capital deve pagar pela crise!

A crise econômica e o contexto ambiental revelam a falência do capitalismo

A crise ambiental é o maior impasse do capitalismo em sua crise global. A escassez de energia, água potável, terras cultiváveis e todo tipo de recursos naturais renováveis se soma às mudanças climáticas e aos impactos imprevisíveis da acelerada extinção de grande número de animais e de vegetais responsáveis pela manutenção de elos preciosos da cadeia alimentar. Diante de um quadro tão grave, os governantes dos países capitalistas reunidos na COP 15 (Conferência da ONU sobre mudanças climáticas) se declararam incapazes de constituir um fundo com irrisórios 100 bilhões de dólares para combater os efeitos mais emergentes das catastróficas mudanças climáticas previstas pelo IPCC (Painel Intergovernamental do Clima). A Rio + 20, com certeza, não avançará em propostas ambientais que comprometam os altíssimos lucros dos usurpadores dos recursos naturais.

Ao redor do mundo, grandes empresas capitalistas alardeiam políticas de sustentabilidade, ocultando que, em última instância, a incontornável necessidade de expansão permanente da produção e consumo de mercadorias reduz seu discurso ambientalista à mera propaganda.

Inúmeras instituições científicas internacionais repetem incansavelmente que a simples manutenção dos atuais padrões de produção e consumo pode culminar em algumas décadas com a liquidação das condições ambientais necessárias, adequadas à preservação da vida, em especial da vida humana no planeta. 
A depredação do meio ambiente também reflete a divisão internacional do trabalho, com a exportação para o terceiro mundo das indústrias intensivas em consumo energético e de materiais, bem como emissoras de grandes volumes de poluentes. Esse processo possibilita uma compatibilização da agenda ambiental com a dinâmica do desenvolvimento do capitalismo nos países centrais, cujo crescimento econômico é cada vez mais alicerçado na tecnologia da informação, nos serviços financeiros e na pesquisa científica, com a consequente desmaterialização da produção. Aos países periféricos ou emergentes - como parte deles, incluindo o Brasil, vem sendo classificados - cabe a produção industrial pesada e altamente poluente. Essa dinâmica revela a total incompatibilidade entre qualquer agenda ambiental séria e o ciclo de desenvolvimento capitalista nos países periféricos.

Eixos e bandeiras de lutas gerais acerca das questões internacionais

A luta contra o sistema capitalista é internacional, por isso a CSP-Conlutas, como uma central claramente internacionalista e em base a análise feita pelos delegados e delegadas desse $1^{\circ}$ Congresso Nacional aprova os seguintes eixos e bandeiras de luta:

- Toda solidariedade aos trabalhadores da Grécia e Espanha!

- Abaixo a reforma trabalhista e todas as medidas antioperárias e antipopulares de Mariano Rajoy na Espanha.

- Abaixo a repressão em Barcelona e todo o Estado Espanhol! Viva a greve geral! Que os capitalistas paguem pela crise!

- Pela libertação dos presos políticos na Espanha e contra a repressão.

- Rechaço à todas as ameaças do governo imperialistas Espanhol e de seus sócios da EU (União Europeia). Denunciamos que o governo não se preste a pagar os saqueadores como busca a associação do Estado com outras empresas imperialistas, seguindo o modelo da "nossa" Petrobras, que deixaria 
em poder de novos saqueadores grande parte da renda petroleira e do Gás.

- Todo apoio e solidariedade à luta dos trabalhadores sírios. Abaixo o Governo Assad. Pela ruptura das relações internacionais do Brasil com a Síria, pondo fim às relações diplomáticas e comerciais enquanto o Governo do Ditador permanecer. Contra a intervenção do imperialismo na Síria.

- Por uma Federação de Repúblicas Socialistas do Oriente Médio e Norte da África!

- Abaixo a intervenção imperialista no Norte da África e Oriente Médio! Pela queda revolucionária das ditaduras nos países árabes!

- Reconhecimento do Estado Palestino e fortalecimento da campanha em defesa da Palestina.

- Fim da agressão de Israel aos palestinos.

- Derrubada do "Muro da Vergonha" na Cisjordânia.

- Liberdade para os presos políticos palestinos que estão nas prisões de Israel.

- Imediata libertação dos presos políticos detidos em Guantánamo e devolução a Cuba da base militar Norte Americana. Fim do bloqueio dos EUA a Cuba.

- Em defesa das conquistas da Revolução Cubana, abaixo o embargo imperialista e a restauração capitalista em Cuba.

- Abaixo "Projeto X", a espionagem e a repressão aos lutadores perpetrada pelo Governo de Cristina Kirchner, na Argentina.

- Pela expropriação da YPF sem indenização e gerida pelos seus próprios trabalhadores. 
- Nenhum centavo dos recursos públicos aos saqueadores da REPSOL!

- Pela unidade da classe operária latino-americana contra o imperialismo!

- Que o governo brasileiro siga este exemplo e estatize o petróleo e o gás do Brasil sob o controle dos trabalhadores.

- Que o governo brasileiro denuncie organismos e tribunais internacionais que se montem contra esta medida do estado argentino

- Que o estado brasileiro não participe de nenhum boicote aos produtos argentinos.

- No $1^{\circ}$ de maio ter como um dos eixos fundamentais o Internacionalismo proletário e o apoio ativo às lutas dos trabalhadores e da juventude na Grécia, Estado Espanhol, Egito e Chile e pelo fim da intervenção imperialista na Líbia, Síria e Oriente Médio.

Sobre a questão dos imigrantes

A partir da divisão feita pela burocracia sindical, governos e burguesia entre trabalhadores nativos e imigrantes, explorando mais esses últimos, muitas vezes não possuindo os mínimos direitos humanos, o Congresso da CSP-Conlutas resolve encampar permanentemente a luta dos imigrantes internacionais e ter a seguinte plataforma de reivindicações:

- Permissão de residência para todos os imigrantes;

- Direito a voto e cidadania a todos os imigrantes;

- Fechamento de todos os campos de detenção de imigrantes;

- Igualdade de salário e condições de trabalho entre nativos e imigrantes;

- Retirada das leis xenofóbicas que limitam a liberdade; 
- Direito de autodefesa de imigrantes contra atos xenofóbos e racistas;

- Unidade de luta entre nativos e imigrantes;

- Permissão para permanecer por tempo indeterminado;

- Pela unidade internacional dos trabalhadores contra políticas racistas e coloniais;

- Solidariedade às revoltas populares no norte da África e Oriente Médio;

- Nova reforma no sistema de pedidos de asilo político;

- Pelo estímulo à sindicalização dos imigrantes legalizados nas suas categorias de trabalho;

- Pelo apoio político aos imigrantes que não são legalizados, pelo seu direito à organização sindical.

\section{Nacional}

Nenhuma ilusão em relação ao Governo Dilma!

Só a luta dos trabalhadores e da juventude pode garantir emprego, terra, saúde, educação e moradia para todos!

Os trabalhadores e a juventude não podem ter qualquer ilusão ou expectativa em relação ao governo Dilma. A manutenção pelos governos Lula/Dilma do modelo da economia brasileira como uma plataforma de produção e exportação de commodities para o mundo, de automóveis e eletrodomésticos para a América Latina, mantém e aprofunda a dependência e vulnerabilidade da economia brasileira aos sobressaltos da economia mundial, enquanto beneficia os banqueiros, o agronegócio e as multinacionais.

Apesar da economia brasileira sentir de maneira ainda limitada os efeitos da crise internacional, o Brasil não está imune à crise. $O$ ano de 2011 encerrou com um crescimento do PIB bastante aquém do esperado, em torno de $2,75 \%$. Há uma desaceleração da economia como 
reflexo da crise internacional, que pode se agravar a partir da própria desaceleração da China, importante parceiro comercial do Brasil. Diante disso, o governo e as patronais, prevenindo-se do agravamento e reflexo da crise internacional no Brasil, realizam uma série de ataques e já preparam outras medidas que representarão novas perdas para os trabalhadores e a juventude.

Assim, Dilma não titubeou em relação ao salário mínimo e aos aposentados, cortou $\mathrm{R} \$ 55$ bilhões do orçamento federal de 2012, o maior corte de toda a história, para garantir o superávit primário, com grave redução nas áreas da saúde ( $R$ \$ 5,5 bilhões), educação ( $R$ \$ 1,9 bilhão) e reforma agrária ( $R \$ 1,2$ bilhão).

O governo compromete toda a economia brasileira ao destinar para o pagamento da dívida pública $49,15 \%$ de todo o orçamento do ano de 2011 e 48\% do orçamento de 2012, muito mais do que com investimentos, pagamento do funcionalismo ou previdência social. O governo do PT, no mesmo estilo do PSDB, retomou o programa de privatização com a entrega dos aeroportos à iniciativa privada, a privatização do sistema público de Saúde, incentiva as PPPs (Parcerias Público Privada) em diversas áreas, como a de transporte urbano, e a abertura do capital das estatais, como a Petrobras e os Correios, além da manutenção dos leilões ao setor privado de petróleo e Gás. Segue com a política das reformas sindical, trabalhista e previdenciária. Tramitam ainda no Congresso Nacional diversos projetos de lei que atacam direitos dos servidores públicos e congelam salários.

No campo, também não foi diferente. O novo Código Florestal, bancado pelo $\mathrm{PC}$ do $\mathrm{B}$ representou um enorme retrocesso na luta ambiental e o fortalecimento do agronegócio. A reforma agrária não avançou no governo Lula e segue parada no governo Dilma.

A tragédia ocorrida na região serrana do Rio de Janeiro foi outra demonstração do desastre político, econômico e social a que estão submetidos os trabalhadores brasileiros. Após um ano nenhuma casa foi construída na serra, nem tampouco no Morro do Bumba, local de nova tragédia ocorrida no ano anterior. 
Por outro lado, para favorecer a especulação imobiliária, o governo do PSDB em São Paulo e a justiça, numa violenta ação policial, desalojaram os moradores do bairro do Pinheirinho em São José dos Campos/SP, construído desde 2004, no qual habitavam cerca de seis mil pessoas, para deixá-las na rua, ao relento, o que mereceu um amplo repúdio da sociedade brasileira e da comunidade internacional.

A operação realizada pela Polícia Militar do governador Geraldo Alckimin no Pinheirinho, com blindados, cavalaria, bombas e armas, teve requintes de crueldade, foi uma expressão da face repressora do estado que se manifesta cada vez mais na constante perseguição e criminalização dos movimentos sociais como ocorrido na prisão arbitrária de manifestantes do ato contra a visita de Obama ao Rio de Janeiro em 2011, na repressão e perseguição na USP - Universidade de São Paulo, e, mais recentemente, na prisão de líderes e ativistas das mobilizações dos militares dos estados da Bahia e Rio de Janeiro, demonstrando as contradições e a deterioração do estado capitalista.

Existe no país um déficit habitacional de 11 milhões de casas e a necessidade de uma reforma urbana que possa dar moradia para os necessitados e melhorar a situação caótica nos bairros populares. Está demonstrada a ineficácia do Programa "Minha casa, Minha vida".

A desocupação do Pinheirinho não é um caso isolado. A realização de megaeventos como a Copa e as Olimpíadas está significando mais ataques aos trabalhadores. Milhares de despejos e remoções forçadas, sem indenização, estão acontecendo, aumentando ainda mais a miséria e empurrando os trabalhadores para as regiões mais periféricas, longe do trabalho e sem acesso à serviços públicos. Esses ataques à população carente são efetuados com uso de violência policial, prisões e ameaças de morte, criminalizando aqueles que lutam por condições dignas de vida e moradia. Os governos federal, estaduais e municipais estão impondo um plano que podemos chamar de contrarreforma urbana, para favorecer a especulação imobiliária. Desencadearam uma campanha de higienização (Favela do Moinho, San Remo/Butantã, Cracolândia etc.), criminalizando e tentando esconder a pobreza. Outros exemplos são as ocupações dos morros cariocas e a instalação das chamadas Unidades de 
Polícia "Pacificadora", a pretexto de combater o tráfico, que apenas migrou para outras regiões. Neste contexto, insere-se ainda a luta das comunidades quilombolas e indígenas, que reclamam a titularização e a preservação de suas terras e cultura, ameaçadas pelo latifúndio, pelo agronegócio, por madeireiros, por grandes empreendimentos e a própria Marinha do Brasil.

É central para a nossa luta, a denúncia da política privatista imposta à saúde pública, através das parcerias público-privadas e as chamadas organizações sociais, que vem ceifando vidas e deixando milhares de crianças, idosos e a população em geral nas filas dos hospitais e postos de saúde. Faltam médicos, remédios e leitos hospitalares, autarquizando hospitais universitários (duas portas de entrada) e com 1/3 das verbas para a saúde sendo desviadas para a corrupção.

Nesse contexto, mulheres, negros e a juventude são os maiores prejudicados. Apesar de ser mulher, a adoção dessas políticas demonstram que Dilma não governa para as mulheres trabalhadoras e demais setores oprimidos. As mulheres trabalhadoras sofrem com a falta de creches, de saúde pública integral e de amparo nas situações de violência. Enquanto isso se assiste o crescimento do racismo e da homofobia.

No cenário internacional, o caráter pró-imperialista do governo Dilma é evidente ao manter o Brasil no vergonhoso papel de chefiar as tropas de ocupação do Haiti. As tropas da MINUSTAH reprimem o povo para tentar estabilizar a situação para o novo governo de Martellly, enquanto assiste-se ao retorno das forças duvalieristas, os macoutes. A decisão do governo brasileiro de limitar a cem o número de vistos aos haitianos além de inédita é discriminatória.

Desde o início de 2011, o governo Dilma se depara com uma série de escândalos de corrupção, que levaram à queda de sete ministros. Agora, a título de desviar a atenção da opinião pública sobre o julgamento do mensalão, o governo aceitou a instalação de uma CPI (CPI do "Cachoeira") que acabou por evidenciar ainda mais um enorme esquema de desvio de verbas públicas e tráfico de influência que atinge todos, governo e oposição. 
Para aplicar sua política, o governo Dilma, desde o primeiro momento, deu continuidade à política de colaboração de classes de Lula, estabelecendo acordos e alianças com mais diversos setores da burguesia e da burocracia sindical, em particular a CUT. Apesar do colaboracionismo das direções majoritárias do movimento, em particular da CUT, de algum crescimento econômico e da popularidade do governo Dilma, assistimos ao maior ascenso grevista dos últimos anos, que conquistou vitórias econômicas importantes, embora não tenham conseguido derrotar o governo e a sua política econômica.

Mas os trabalhadores e os movimentos populares não se intimidaram e foram à luta, sob o lema "Se o Brasil cresceu, os trabalhadores querem o seu". Assim, o primeiro ano do governo Dilma foi marcado pela retomada das lutas operárias e demais setores da classe trabalhadora, aumentando a polarização social. De norte a sul do país ocorreram greves e mobilizações. Operários da construção pesada e civil e os metalúrgicos, com destaque para os trabalhadores das montadoras de automóveis, protagonizaram greves que conquistaram importantes vitórias econômicas. Nas obras do PAC assistimos a verdadeiras rebeliões contra as condições de trabalho. Petroleiros, químicos, gráficos, mineiros e trabalhadores da alimentação se somaram a essa onda de lutas. Bancários, trabalhadores dos Correios realizaram greves nacionais. No setor de transportes, os trabalhadores da CPTM paralisaram em São Paulo. O funcionalismo público foi à luta: servidores ligados à Fasubra, Sinasefe, Judiciários, entre outros, realizaram longas greves. A educação foi destaque: houve greves em nada menos do que vinte e dois estados brasileiros, apesar da maioria da direção da CNTE se recusar a unificar o movimento. Bombeiros militares do RJ protagonizaram um enfrentamento duríssimo com o Governador Sérgio Cabral, que provocou uma comoção, servindo de exemplo para outras corporações militares e civis de outros estados como Bahia, Ceará, Paraíba e Maranhão. A CSP-Conlutas teve uma destacada atuação em todas essas lutas, defendendo sua unificação.

Não há dúvidas que somente a organização, mobilização e unificação das lutas dos trabalhadores e da juventude poderão garantir emprego, terra, saúde, educação e moradia para todos. $\mathrm{O} 1^{\circ}$ Congresso 
Nacional da CSP- Conlutas reafirma seu apoio a todas as lutas e chama à construção de um plano de ação que unifique, em uma jornada comum, todas as mobilizações contra as políticas anti-trabalhador do governo Dilma e da burguesia.

\section{Sobre as eleições}

Os trabalhadores e a juventude não podem ter ilusão no governo Dilma, que esteve ao longo do ano de 2011 envolvido numa série de escândalos de corrupção que levaram à queda de sete ministros. Tampouco as alternativas da oposição burguesa, como o PSDB, DEM e PPS ou variantes que participam do governo Dilma, como o PSB e $P V$, são solução.

A Central não pode ficar alheia a um momento de debate político e de alternativas para a sociedade como o das eleições municipais. Respeitando a autonomia das organizações e movimentos filiados, a Central deve intervir junto aos trabalhadores de suas bases e apresentar a sua plataforma de reivindicações.

Assim o $1^{\circ}$ Congresso deve indicar aos trabalhadores e aos movimentos sociais a rejeição veemente dos candidatos da oposição burguesa (PSDB e seu bloco) e da base aliada do governo Dilma (PT/PMDB e aliados) e reafirmar a compreensão de que a única saída para que nossa classe seja vitoriosa é a conquista de uma nova sociedade, justa e igualitária, governada pelos trabalhadores, uma sociedade socialista.

Nesse contexto, o $1^{\circ}$ Congresso da CSP-Conlutas, identificando o aprofundamento da crise capitalista e o consequente recrudescimento dos ataques à classe trabalhadora brasileira, afirmar o programa anti-governista da nossa central e a necessidade de enfrentamento ao governo Dilma / PT e seus aparatos de sustentação nos movimentos sociais. Afirmamos a necessidade de um programa classista para enfrentar a crise, os ataques do governo Dilma / PT e dos patrões, pautado pela unidade classista em oposição à política de conciliação das centrais pelegas e governistas.

Construir uma frente social e política na busca do poder dos trabaIhadores e do povo 
A principal contradição da realidade brasileira opõe aos interesses da ampla maioria do povo e dos trabalhadores aqueles representados pelo capital internacional, pelos grandes monopólios e pelo grande latifúndio. Portanto, a revolução brasileira será obra de milhões de sujeitos das mais variadas concepções filosóficas, ideológicas, religiosas e políticas. Entender a construção da revolução brasileira como obra do povo trabalhador organizado é o que nos diferencia das seitas, do sectarismo e intolerância.

A tarefa central colocada na ordem do dia passa pela construção de uma aliança da classe trabalhadora com todos os explorados que unifique politicamente toda a base social que se choca de forma antagônica com o domínio do grande capital e suas expressões políticas consequentes.

Se a construção do socialismo no Brasil só poderá ocorrer como obra realizada pela maioria do povo, ou seja, a classe trabalhadora, a construção dessa frente social e política é imprescindível, pois, nenhuma organização isoladamente será capaz de aglutinar esta maioria.

A construção dessa frente terá que se desenvolver com o objetivo de conquistar o poder político e colocá-lo a serviço desta ampla maioria da qual ela será a expressão. Por isso é preciso abrir o debate sobre esta necessidade inadiável com os setores do movimento sindical, das organizações da juventude, da luta pela terra, da luta em defesa dos direitos civis, dos direitos humanos, do movimento ambiental e dos pequenos proprietários em processo de empobrecimento.

Devemos apresentá-la aos partidos de esquerda e movimentos que expressem esses fenômenos. Uma aliança da classe trabalhadora com todos os explorados para o povo

brasileiro é uma tarefa urgente e terá que ser também renovadora, da qual a CSP-Conlutas será protagonista.

Construir a unidade sólida com a população

É preciso reafirmar que o tipo de organização sindical e popular de nossa central permite criar laços orgânicos com a população pobre, através da elaboração de políti-cas para as diversas categorias em seus locais de moradia, estudo, lazer, considerando suas necessidades mais 
sentidas e que muitas vezes se estendem para além de suas necessidades economicistas, tais como a luta por moradia, educação, saneamento, contra a violência dos grandes centros urbanos, etc. Uma Central classista na atual fase de organização do movimento sindical, precisa entender que sua ação deve estar voltada para construir novas relações com sua base social, ou estará fadada à derrota e ao isolamento. Só dessa forma é possível fazer o enfrentamento à grande Frente Burguesa que se formou em torno do governo de Lula, e agora de Dilma, do PT.

Apesar do esforço militante, tanto no campo político, quanto no sindical, que foi feito pelo conjunto da aguerrida militância socialista, que não se vendeu ou se deixou cooptar, para construir cada uma destas alternativas, elas só poderão se transformar em algo que tenha capacidade de ataque se unificadas. A Central pode se constituir em uma Grande Frente Sindical e Popular, que consiga atrair para a justeza de sua política setores importante da classe trabalhadora brasileira, que apesar de ter sua centralidade mantida nos setores formais, conta hoje com uma cara completamente nova, que tem que ser entendida para ser organizada com suas bandeiras específicas.

Esse tipo de intervenção permite dialogar mais profundamente com a nossa classe, fazer a propaganda da política socialista, e mais ainda, envolver setores pobres e indignados com a ordem, que conseguem encontrar por onde canalizar sua revolta e entender que precisam de muito mais do que vender seus votos para fazer com que sua condição miserável mude. A capacidade de mobilização com este tipo de perspectiva de organização política é muito superior, mesmo em uma fase de refluxos, o que nos leva a crer que o potencial de mobilização de um instrumento como este em uma fase de ascenso pode ser determinante para nossas lutas.

Não ao pacto social travestido de luta contra a desindustrialização!

As centrais sindicais governistas têm articulado junto com as entidades patronais um movimento "contra a desindustrialização". Segundo eles, é preciso que patrões e trabalhadores somem forças para fazer frente as ameaças que está sofrendo a indústria "nacional" com a concorrência dos produtos importados. Por isto é que estão realizando atos em todo 
país, com manifestações que unem capital e trabalho em um "Acordo nacional em defesa da produção e do emprego“.

Para a CSP-Conlutas, isto se trata de mais uma armadilha contra os interesses da classe trabalhadora. Atrás de todo palavreado de que é preciso unir a todos em defesa dos empregos e da indústria, se esconde a verdadeira intenção dos empresários de aumentarem cada vez mais seus lucros, com a cumplicidade daquelas centrais sindicais. Tanto é assim que as principais reivindicações deste movimento, passam bem longe de demandas dos trabalhadores como redução de jornada e estabilidade no emprego.

Com a recente desaceleração da economia no Brasil, realmente houve uma queda na produção da indústria de transformação que saiu de um crescimento de 10,5\% em 2010 e ficou próximo a zero no ano passado. No entanto, a maior parte das importações, responsáveis por esta queda, foram feitas pelas empresas multinacionais instaladas aqui, uma vez que procuram outros mercados para manter seus lucros diante das dificuldades causadas pela crise que atinge com mais força os países centrais. Exemplo disto é a indústria automobilística que apesar de toda a choradeira tem como maiores importadores a GM, a Volks e a Ford. Portanto, não será junto com estes patrões que as importações serão enfrentadas.

Outra tentativa de enganação é dizer que este movimento é para proteger a "indústria nacional". As grandes empresas do setor são controladas pelas multinacionais. Não existe nenhuma montadora nacional de automóveis, o setor eletroeletrônico é quase todo de capital estrangeiro, assim como é grande parte da economia.

São estas mesmas empresas multinacionais que enviaram nos últimos anos, mesmo com a crise, milhões de dólares para suas matrizes, através da remessa de lucros e dividendos, totalmente livre de impostos. Uma verdadeira sangria da riqueza nacional. Assim, os benefícios concedidos a este setor, longe de significar apenas o aumento de emprego, significa a transferência de recursos do país para as grandes potencias imperialistas.

O verdadeiro motivo que está revoltando o setor da indústria de transformação é que suas margens de lucros são inferiores aos ganhos de 
outros setores, como a mineração, o agronegócio e os bancos. Por isto, querem compensações do governo. Ainda assim, as margens de lucro da indústria da transformação no Brasil é bem superior às conseguidas nos EUA, por exemplo, devido aos baixos salários e aos altos preços dos produtos monopolizados, entre eles o carro.

A política industrial do governo Dilma se resume a transferir dinheiro público para os empresários. E mais uma vez ouvindo os apelos destes resolveu tomar uma série de medidas (que levarão a uma injeção de 65 bilhões aos cofres dos empresários), entre elas a desoneração da folha de pagamento para diversos setores, acabando com a contribuição patronal para a previdência de $20 \%$ e instituindo um desconto sobre o faturamento que varia de $1 \%$ na indústria, até $2,5 \%$ no setor de serviços. Mais uma vez quem vai pagar a conta são os trabalhadores e os aposentados, pois tais medidas levarão a um tremendo rombo nas contas da previdência, o que aumentará a pressão para a sua privatização e a manutenção do famigerado fator previdenciário. Ainda assim, muitos patrões reclamam, acham que as medidas são tímidas e querem mais. Este é o resultado prático do pacto social. Sempre os empresários saem ganhando e os trabalhadores saem perdendo. Basta lembrar as famosas câmaras setoriais, em 1993, que serviram para flexibilizar parte das leis trabalhistas no país.

A CSP-Conlutas se posiciona contrária a este "Acordo nacional em defesa da indústria e do emprego", não participará das "manifestações" com os empresários e denunciará esta armadilha e as centrais sindicais que o apoiam. Devemos a partir das reivindicações concretas dos trabalhadores (as) lutar por: aumento geral de salários, estabilidade no emprego, redução da jornada de trabalho para 36h sem redução salarial, não pagamento da dívida interna e externa, contra a política econômica do governo Dilma e chamar a nossa classe a lutar por um plano econômico dos trabalhadores que rompa com a dependência do capital estrangeiro e das multinacionais .

Sobre a participação da CSP-Conlutas na Mesa Nacional da Indústria da Construção

A CSP-Conlutas passa a compor a "Mesa Nacional Permanente Para o Aperfeiçoamento das Condições de Trabalho na Indústria da Construção" para o acompanhamento do cumprimento do 
"Compromisso Nacional Para o Aperfeiçoamento das Condições de Trabalho na Indústria da Construção", buscando ser porta voz das lutas, das greves e das reivindicações dos operários e exigir do Governo e das empreiteiras a imediata efetivação do "Compromisso Nacional" em todas as obras, bem como, o atendimento imediato de todas as reivindicações dessa categoria.

As greves dos operários das obras do PAC ocorridas no ano de 2011 obrigaram o governo a estabelecer uma mesa nacional de negociação, envolvendo os empresários, os sindicatos, federações, confederações de trabalhadores da indústria da construção e todas as centrais sindicais. Após oito meses de negociação, no último dia $1^{\circ}$ de março de 2012, foi anunciado em Brasília - pela presidente Dilma - com a presença de centenas de representantes de entidades patronais, de trabalhadores e do governo um acordo denominado: Compromisso Nacional Para Aperfeiçoar as Condições de Trabalho na Indústria da Construção (De caráter opcional e com um critério de adesão como quis o Governo)

A CSP-Conlutas que esteve no início das negociações com o Governo e rompeu em protesto às quatro mil demissões ocorridas em Jirau no auge das mobilizações de 2011, esteve presente no lançamento desse acordo e apoiada na realidade concreta de um novo levante de greves, irá compor, a partir de agora, a "Mesa Nacional Permanente para o Aperfeiçoamento das Condições de Trabalho na Indústria da Construção" que, formalmente, terá o papel de acompanhar a implantação do referido termo.

O anúncio desse acordo, com seu caráter de "adesão", está longe de mudar a dura realidade dos operários nas obras. Em primeiro lugar porque se trata de um "Compromisso" que reflete apenas indicativos sobre as condições mínimas de trabalho. Por outro lado, a sua existência é devida ao ascenso de lutas e greves de dezenas de milhares de trabalhadores que seguem submetidos a condições degradantes de trabalho, em um dos setores mais explorados de nossa classe, e que por esse motivo se levanta e enfrenta os governos, as empresas, a repressão e a ausência flagrante do comprometimento de boa parte de suas "representações" sindicais. 
Em segundo lugar, porque só estabelecer o acordo não basta. É preciso colocá-lo em prática. As inúmeras greves que voltaram a explodir nos grandes canteiros, com a mesma intensidade, pelos mesmos motivos mostram que a situação continua como antes. Os trabalhadores seguem sendo tratados com a mesma truculência e/ou conivência dos governantes e arrogância da patronal. Exemplos são os episódios de humilhação e repressão policial praticados pelo Consórcio Construtor de Belo Monte, bem com as centenas de demissões efetivadas como forma de punir os operários que lutam por melhores condições de trabalho nas diversas obras desse País

O objetivo do Governo com essa mesa (dirigida pela Secretaria Geral da Presidência, com nove ministérios, os representantes da patronal e de parte dos sindicalistas alinhados com o Palácio do Planalto) é tentar controlar o movimento, estabelecer um interlocutor e construir uma mesa de gestão política e econômica, a exemplo, do que foram as câmaras setoriais.

O nosso objetivo é o oposto: levar para essa mesa o reflexo dessas mobilizações e greves. Aí atuaremos, e em todos os espaços onde for possível defender os interesses dos trabalhadores, para exigir do Governo Dilma e das empreiteiras a imediata efetivação do acordo nacional em toda obra, em cada empresa, em cada complexo ou região. É essa a cobrança que faremos permanentemente.

Queremos uma mesma data-base, piso nacional e mesmo salário para os operários em todo o país, cesta básica com valor igual, pagamento de horas-extras e horas in itinere, folga (baixada) de 5 dias a cada 60 dias trabalhados, Plano de Saúde com cobertura nacional para todos os nossos familiares, saúde, segurança, condições de trabalho, alojamento, transporte, refeição de qualidade e ainda a possibilidade de indicação de até sete delegados sindicais de base em cada obra com estabilidade no emprego.

A nossa grande e principal tarefa, ao compor essa mesa, seguirá sendo a de potencializar a luta direta, a construção da unidade nacional desse setor, com a diretiva de derrotar as intenções do governo e 
das empreiteiras com seu "projeto de desenvolvimento" e conquistar melhores condições de trabalho e salários.

O fortalecimento do trabalho e organização de base dessa categoria é condição determinante para que se estabeleça uma alternativa de direção para esse setor e, consequentemente, para a nossa classe, partindo das lutas objetivas até construção e consolidação de relações que nos permitam a legitimidade política para representar e ser representados por esses trabalhadores, apoiando e estimulando sua mobilização permanente.

A CSP-Conlutas utilizará esse acordo, que reflete demandas e orientações sobre condições mínimas de trabalho para buscar ser uma interlocutora dessas lutas e reivindicações. Caso se tente usar esse espaço para retirar algum direito ou para buscar dar legitimidade há algum ataque dos empresários sobre os trabalhadores, seremos veementemente contrários, pois nunca integraremos um espaço que sirva para rebaixar direitos dos trabalhadores e vise preservar o lucro dos grandes empresários.

Em cada uma dessas obras os operários da construção estão lutando pelas mesmas coisas, com pautas semelhantes e sob um mesmo grau de opressão e exploração, portanto, devemos exigir imediatamente do Governo Dilma e das empreiteiras:

- Efetivação desse acordo em todas as obras;

- A mesma data-base;

- Aumento geral dos Salários;

- Um piso nacional e o mesmo salário, no país inteiro, para os profissionais;

- Cesta básica com valor igual em todo país;

- Pagamento de horas-extras e horas itíneres; 
- Folga (baixada) de 5 dias a cada 60 dias trabalhados, com passagens aéreas pagas pelas empresas;

- Plano de saúde com cobertura nacional para todos os nossos familiares;

- Eleição de representantes sindicais de base em cada obra, com direito a estabilidade no emprego;

- Saúde, Segurança, Condições de Trabalho, alojamento, transporte e refeição de qualidade;

- Nenhuma demissão.

Resolução sobre a criminalização das greves da PM e dos Bombeiros

Os anos de 2011 e 2012 foram marcados por importantes processos de mobilização em corporações militares, como das PMs do Ceará e Bahia e do Corpo de Bombeiros do Rio de Janeiro. As greves são justas e as reivindicações dos grevistas já eram de conhecimento dos governos estaduais há muito tempo. No entanto, nenhuma ação prática foi adotada por esses governos para atender as demandas da categoria - exceção ao Ceará onde a greve foi vitoriosa e o governo foi obrigado a atender as reivindicações da categoria.

O mesmo descaso que os governos de todos os estados têm demonstrado com a categoria dos policiais e com a segurança pública, também se repete em outras categorias e áreas, como na saúde e educação, por exemplo. Ilegal foi a postura do governo Jacques Wagner-PT, por exemplo, que não pagou a URV (Unidade Real de Valor) aos policiais militares e a todos os servidores públicos estaduais, mesmo com determinação judicial para tal. Também é ilegal não cumprir acordos fechados com as categorias, como tem sido a prática do referido governo.

As greves da PM e dos Bombeiros mostram a necessidade não apenas da recomposição salarial dessas categorias, mas de uma mudança no funcionamento e objetivos dessas corporações, que inclua a desmilitarização e o direito à sindicalização. 
No momento em que se realiza o $1^{\circ}$ Congresso da CSP- Conlutas, os delegados e delegadas presentes reafirmam o apoio às greves $\mathrm{e}$ aos movimentos dos policiais militares e dos bombeiros. Contudo, no marco desses importantes processos, entendemos como necessário dialogar com os esses trabalhadores sobre qual deve ser o papel da polícia frente aos movimentos sociais. Quando em greve, os policiais buscam o apoio da população para o seu movimento legítimo. Ou seja, o apoio dos rodoviários, comerciários, bancários, professores, estudantes, servidores públicos e de toda a população. Assim como as greves da PM e dos Bombeiros são justas e não devem ser tratadas como crime e sim como um direito, todas as greves e lutas dos outros trabalhadores são justas e não devem ser reprimidas pela PM. Em uma ocupação de terra ou de imóvel por trabalhadores que lutam por emprego, salário e moradia, a polícia não deve reprimir o movimento, como ocorreu na violenta e desumana desocupação do Pinheirinho, em São José dos Campos - SP, por exemplo.

A mesma insubordinação, corajosa e legítima, que fez com que os companheiros paralisassem suas atividades e enfrentassem o poder burguês constituído, também deve estar presente quando as outras categorias estiverem lutando, interrompendo as vias da cidade e ocupando prédios públicos e terrenos abandonados. Só é possível que as reivindicações de todos os trabalhadores sejam atendidas

-inclusive a dos policiais - se estivermos unidos e que a polícia sirva para combater a criminalidade e não os movimentos sociais.

Nesse sentido, além de defendermos as greves e as lutas dos policiais militares e bombeiros, exigimos dos governos a revogação de toda e qualquer punição decorrentes desses movimentos, sobretudo em relação à greve dos bombeiros do Rio de Janeiro. É preciso denunciar a política fascista do governo Sérgio Cabral, que criminalizou, demitiu e aplicou severas penas contra as lideranças grevistas, inclusive seu principal dirigente, o Cabo Daciolo, que foi exonerado da corporação. $\mathrm{O} 1^{\circ}$ Congresso da CSP-Conlutas convoca todas as suas entidades e organizações filiadas a prestarem apoio e solidariedade aos militares atingidos por esses processos, deflagrando uma campanha 
nacional pela reintegração dos demitidos, revogação das punições e apoio às suas famílias.

Resolução sobre a PEC do trabalho escravo

Considerando:

- Que a PEC-438, que tramita no Congresso Nacional desde 2001, tendo sido aprovada no Senado em 2004, tem votação prevista na Câmara dos deputados nos dias 8 ou 9 de maio próximo;

- Que esta PEC regulamenta a possibilidade de expropriação sem indenização de propriedades rurais ou urbanas onde se constate trabalho análogo à escravidão, propriedades que deverão ser destinadas à programas de reforma agrária (rurais) e programas de moradia popular (urbanas);

- Que, obviamente, dada a composição do legislativo brasileiro, estão em curso pressões para inviabilizar a aprovação da referida PEC, seja votando contra, seja negando quórum no plenário da Câmara;

O $1^{\circ}$ Congresso Nacional da CSP-Conlutas resolve:

Somar-se ao esforço que vem sendo desenvolvido por várias organizações dos trabalhadores, entidades ligadas aos direitos humanos e organizações democráticas,para pressionar os deputados para a aprovação da referida PEC; Divulgar pelo site da entidade e listas de e-mails da central, as iniciativas no sentido de fortalecer esta pressão positiva (como o abaixo assinado eletrônico que circula na Internet ver <www.trabalhoescravo.org.br>). Conclamar a todos os sindicatos, movimentos e organizações que fazem parte da nossa central, a que se somem a este esforço e se manifestem junto aos parlamentares pela aprovação da PEC 438;

Enviar, ainda na semana do primeiro de maio uma nota da Central a todos os deputados, em nome deste Congresso reclamando a aprovação da PEC 438; 
Levar esta bandeira à manifestação do $1^{\circ}$ de Maio;

Enviar delegação da Central nos dias 8 e 9 de maio a Brasília, para participar de ato político no auditório Nereu Ramos, na Câmara dos Deputados.

Resolução sobre as mortes no campo

Considerando:

- Que voltou a crescer o número de assassinatos no campo, sendo que nas últimas semanas foram assassinados três trabalhadores (as) no triangulo mineiro, quatro em Rondônia, um no Maranhão e um em Pernambuco. Além dos assassinatos, segue em níveis assustadores o número de trabalhadores e trabalhadoras do campo ameaçados de morte;

- A prática das ameaças e dos assassinatos das lideranças sociais tem sido cada vez mais usadas por fazendeiros, madeireiros e grandes empresários também contra as comunidades quilombolas e nações indígenas;

- A falta de ação das autoridades, locais e nacionais, criam um ambiente de impunidade que permite ampla liberdade de ação tanto aos assassinos de trabalhadores quanto aos responsáveis pelas ameaças. Quando muito se identifica e processa o assassino, deixando de fora os mandantes (normalmente grandes empresários), verdadeira fonte da violência no campo;

- Pela necessidade de uma ação frente a esta situação, que articule todos os setores interessados em parar os assassinatos e dar visibilidade ao problema. Para aumentar a pressão sobre governos e instituições (do judiciário, executivo e legislativo) no sentido de forçar a adoção de medidas concretas que ponham fim a esta situação;

O $1^{\circ}$ Congresso da CSP-Conlutas resolve: 
- Retomar a campanha contra os assassinatos no campo, exigindo a apuração e punição dos assassinos e mandantes;

- Delegar à SEN a tarefa de articular, no prazo de tempo mais curto possível, uma atividade com a participação de trabalhadores ameaçados e suas organizações, instituições democráticas (como a OAB), instituições como o MPT (Ministério Público do Trabalho), que trate do assunto e formule propostas concretas para enfrentar esta situação.

\section{Tema 2 - Balanço de Atividades e de Organização da Central}

\section{Balanço e Organização}

A fundação da CSP-Conlutas, unificando movimentos populares, estudantis e de luta contra as opressões, além dos sindicatos, significou um passo à frente na reorganização dos setores combativos dos movimentos sindicais e populares brasileiros.

Nesse breve período de vida da nossa Central, a CSP- Conlutas atuou em diversas campanhas políticas, nas lutas das categorias, eleições sindicais e congressos, jornadas do movimento popular, lutas estudantis, plebiscitos populares, dentre outros.

Desenvolveu a solidariedade internacional e esteve presente em atividades em diversos outros países como a Palestina, Egito, Espanha, França, Itália, Paraguai, Argentina, Haiti, Chile e outros.

A intervenção da Central nas greves das obras do PAC em 2011 catapultou a Central a um plano de destaque nacional, pelo seu papel no apoio à mobilização. A central teve papel importante também na Greve no setor Petroleiro em Novembro de 2011.

A CSP-Conlutas teve atuação destacada em todas as lutas e trabalhou incansavelmente pela sua unificação, capitaneando um dia de mobilização nacional, em 28 de abril de 2011 e, de 17 a 26 de agosto de 2011, foi a vanguarda da jornada nacional de mobilização, que culminou com a Marcha em Brasília no dia 24 de agosto, ponto alto das 
atividades, que reuniu vinte mil manifestantes, com destaque para as colunas da Central e de suas entidades filiadas.

A unidade de ação ampla conquistada na jornada foi uma vitória importante. As bandeiras levantadas pelos segmentos participantes contendo a denúncia das políticas do governo e as exigências das categorias e movimentos populares e estudantis conferiram, objetivamente, à manifestação, um caráter de protesto contra o governo Dilma.

A Central foi um ponto de apoio político, material e financeiro das lutas do setor do movimento popular organizado na Resistência Urbana - Frente Nacional de Movimentos e iniciou o processo de organização do setor da Central no movimento popular do campo.

A CSP-Conlutas impulsionou diversas campanhas políticas, dentre elas a campanha contra a criminalização dos movimentos sociais, a campanha pelos $10 \%$ do PIB Produto Interno Bruto - para a educação pública, a defesa das empresas públicas, Correios e $\mathrm{Pe}$ trobras, por exemplo, e dos serviços públicos, sendo parte ativa das lutas contra o aumento das passagens e de diversas outras lutas nas regiões, além de campanhas políticas relacionadas às lutas contra a opressão e a discriminação, buscando fortalecer novos instrumentos como o Movimento Mulheres em Luta e o Movimento Nacional Quilombo Raça e Classe.

Essencialmente, consideramos o balanço de atividades de nossa Central como bastante positivo. Não há como desconsiderar os limites da realidade política em nosso país, em particular o apoio majoritário da população aos governos Lula e Dilma e o papel da maioria das direções sindicais e políticas de apoio ao governo. Nesse cenário, manter e avançar na consolidação de uma pequena, mas muito útil ferramenta para as lutas dos trabalhadores e do povo pobre, não é pouca coisa.

Reivindicamos a experiência acumulada nos últimos anos na construção de uma organização sindical e popular combativa, como algo novo na história de nosso país, ainda que, como em toda experiência, tenhamos muitas limitações.

Temos muito ainda que avançar, seja na estruturação da Central, na plena incorporação dos movimentos populares, estudantis e de luta 
contra as opressões, no combate às práticas discriminatórias no interior de nossas entidades, ao machismo e ao preconceito, no combate à burocratização nas entidades sindicais e no fortalecimento de nossa organização de base. São deficiências que não hesitaremos em enfrentar.

Precisamos avançar na política de fortalecimento de nossa alternativa. De um lado, precisamos fortalecer a organização da Central nos estados, consolidando as coordenações e secretarias estaduais, a incorporação de todos os setores que atuam na Central e garantir a contribuição financeira regular.

De outro, temos o desafio de alcançar o reconhecimento pleno como central sindical junto ao Ministério do Trabalho e Emprego. Trata-se de um direito que não podemos nem devemos abrir mão. Embora organizemos quase duas centenas de sindicatos, uma parte muito grande dessas entidades não tem sua situação regularizada junto ao MTE

-Ministério do Trabalho e Emprego. Parte desse problema deve ser debitada à burocracia e ao aparelhamento político do Ministério por setores do governo. Mas outra parte deve-se ao tratamento dado por nossos sindicatos aos problemas que envolvem a sua situação legal. Ou seja, tem a ver com nossa compreensão ou incompreensão política da importância da legalidade como instrumento de defesa da nossa classe no estado burguês. Os patrões e governos, muitas vezes, têm se utilizado dos problemas burocráticos que envolvem a situação das entidades sindicais para atacar e criminalizar nossos movimentos, seja através do não reconhecimento dos sindicatos, da recusa à negociação coletiva, da retenção das contribuições dos associados ou da demissão de dirigentes sindicais.

Outros pontos de organização:

A Central deve incentivar o funcionamento regular das coordenações estaduais, que resultem em iniciativas de elaboração, divulgação e mobilização da Central, dentro dos seguintes propósitos:

- A CSP-Conlutas deve continuar avançando junto à base de cada sindicato. 
- Os sindicatos e movimentos populares devem reproduzir as discussões do $1^{\circ}$ Congresso da CSP-Conlutas junto a sua base.

- A Central deve seguir fortalecendo e estimulando o fundo de apoio às eleições de oposições sindicais.

- A CSP-Conlutas enquanto uma central independente, classista e anticapitalista, que articula a classe trabalhadora para além do movimento sindical, articule as campanhas políticas que advirem dos sindicatos e associações sindicais, com as entidades do movimento estudantil e popular e vice-versa, por exemplo, campanha salarial dos servidores federais, etc.

- A CSP-Conlutas, enquanto espaço alternativo à falência da CUT deve procurar, de maneira sistemática, pequenos sindicatos e associações sindicais não filiadas as centrais sindicais para iniciar trabalho conjunto e de filiação, tendo em vista a necessidade da busca pela ampliação da base da central e a expansão de segmento da classe trabalhadora por ela representada.

- Para dinamizar as regionais da CSP-Conlutas é preciso aprofundar a política de construção, que abranja:

- Organização, em nível regional pela CSP- Conlutas, de manifestações públicas de $1^{\circ}$ de maio, Dia Internacional da Mulher, Dia da Consciência Negra, e outras situações do movimento operário, embasadas em plataformas políticas específicas.

- Organização da participação dos trabalhadores em campanhas públicas unitárias, que façam avançar a limitada consciência anti-imperialista.

- Estimular os sindicatos e movimentos populares a divulgar através dos seus boletins as lutas internacionais dos trabalhadores e organizar campanhas públicas de solidariedade. 
- Estimular o crescimento da consciência política internacional e anti-imperialista entre os trabalhadores.

- A CSP-Conlutas deve seguir com a política de afirmação da Central nas diversas regiões, e sua política independente das centrais de colaboração de classe.

- A CSP-Conlutas deve estimular a realização de seminários ou encontros estaduais para a discussão de conjuntura e ação política;

- A Central deve estimular em todo o país o funcionamento regular das Coordenações Estaduais, com reuniões massivas, que resultem em iniciativas de elaboração, divulgação e mobilização da Central.

Para seguir avançando em sua construção sindical e popular a Central deve:

- Incluir as pautas políticas do movimento popular como parte fundamental de suas pautas, no debate cotidiano e nas jornadas que integra. Implica em manter estas pautas em seus materiais públicos (site, boletins, panfletos), na definição dos temas das reuniões da SEN, das reuniões de Coordenação Nacional e em sua intervenção nos espaços de unidade de ação da esquerda.

- As reuniões da Coordenação Nacional da CSP-Conlutas devem incluir, em sua preparação, a preocupação com elementos de simbologia que facilitem a integração dos militantes do movimento popular nestes espaços. É importante também o esforço na busca das condições materiais de participação destes militantes (transporte, alojamento e alimentação) em igualdade àquelas disponibilizadas aos militantes sindicais por suas entidades.

- A Central deve construir uma Campanha de debate junto às entidades filiadas, com a realização de encontros e seminários, sobre a importância da integração entre movimento popular e sindical para a unidade dos trabalhadores, bem como 
estimular a realização de iniciativas conjuntas na base onde isso for possível, particularmente entre os sindicatos de servidores públicos e de trabalhadores da construção civil.

\section{Tema 3 - Organização de Base e Plano de Ação}

Organização de Base

Considerando:

- Que a organização de base (entendida aqui como organização para a luta dos trabalhadores nos locais de trabalho, moradia, estudo, etc.) é fundamental para o fortalecimento da luta dos trabalhadores, para a democratização das nossas entidades e movimentos, e também para a educação da nossa classe para a sua autodeterminação, fundamental para o nosso projeto de sociedade socialista e libertária, governada pelos próprios trabalhadores;

- Que, justamente por essa razão, a organização dos trabalhadores a partir da base é parte constitutiva e fundamental da concepção de organização na qual se baseia a construção da CSP-Conlutas;

- Que a realidade atual existente na base dos nossos sindicatos (principalmente, mas também das demais organizações que compõem a nossa central) está longe de corresponder a esta nossa concepção. Fruto de heranças e circunstancias históricas que antecedem a construção da nossa Central, salvo exceções, os sindicatos e movimentos que compõem nossa Central também padecem com um processo de organização de base muito frágil, em muitos casos praticamente inexistente;

- Que esta situação ameaça objetivamente o projeto que estamos construindo. Não há projeto de organização para a luta dos trabalhadores, não há projeto de sociedade socialista, igualitária e libertária, que sobreviva na ausência de democracia operária e de autodeterminação dos trabalhadores. E não 
há democracia operária ou construção de uma cultura de autodeterminação da nossa classe na ausência de organização dos trabalhadores a partir dos seus locais de trabalho, moradia, estudo, etc. Este é um passo que devemos e podemos dar neste sentido, no momento atual da luta de classes;

- Que é necessário reverter este quadro para aproximar mais a nossa estrutura de organização da concepção política que a embala, seja avançando na organização dos trabalhadores na base, seja avançando na formação sindical e política de ativistas e dirigentes na perspectiva do projeto que defendemos para a luta dos trabalhadores e para a transformação da sociedade;

- Que a luta para reverter esta situação se dá no âmbito da prática cotidiana das organizações, mas não só. No Brasil, herança também do Varguismo e fruto da natureza autoritária do Estado, não há direito à organização no local de trabalho, prevalecendo a ditadura do capital sem nenhum tipo de mediação. Daí a necessidade da luta pela conquista deste direito democrático dos trabalhadores, o de organizar-se no seu local de trabalho;

- Que as bases para este esforço da Central, que deverá ser permanente, foram estabelecidas no Seminário Nacional sobre Organização de Base que realizamos em Novembro de 2010, em São Paulo.

O $1^{\circ}$ Congresso da CSP-Conlutas resolve:

- Tomar esta questão - fazer avançar a organização de base como tarefa central, prioritária, de nossa Central, lutando para fazer com que os sindicatos e movimentos que fazem parte da CSP-Conlutas venham trabalhar com este mesmo critério. Neste sentido, queremos dar continuidade à luta contra a burocratização dos sindicatos iniciada anos atrás na antiga Conlutas;

- No âmbito da Central, dar curso a todas as iniciativas possíveis (junto aos poderes Legislativo, Judiciário e Executivo) no sentido 
de conquistar a proteção legal ao direito de organização no local de trabalho, ou seja, o direito de eleger representantes dos trabalhadores nos locais de trabalho e a garantia de emprego dos representantes eleitos. Esta atividade deve ser tomada como uma campanha prioritária e permanente da Central;

- Atuar junto aos sindicatos filiados à Central no sentido de incentivar, estimular e apoiar as entidades para que, no âmbito de sua atuação o tema organização de base seja também tomado como prioridade. Para que nas atividades cotidianas dos sindicatos, nas campanhas salariais, nas greves, seja uma obsessão organizar os ativistas de base para atuarem junto com a diretoria do sindicato nas discussões e decisões relativas à luta e à ação do sindicato;

- Neste sentido, aproveitando experiências desenvolvidas no setor metalúrgico e da construção civil, estimular os sindicatos a tomarem como reivindicação central nas campanhas salariais a implantação dos delegados sindicais nas empresas, lutando para incorporar este direito às convenções coletivas da categoria;

- Propor aos sindicatos que estabeleçam em sua estrutura de direção, instâncias (conselho de representantes, por exemplo) que permitam a participação efetiva dos ativistas organizados nos locais de trabalho nas discussões e decisões mais importantes a serem tomadas pela entidade;

- Orientar as oposições sindicais ligadas à Central que tratem também este tema como prioridade, seja a partir da sua prática cotidiana, apoiando o trabalho da oposição na organização dos trabalhadores dentro das empresas, seja levantando a bandeira da organização de base como programa da oposição e denúncia da burocracia sindical;

- Propor aos movimentos filiados à nossa Central que, considerando as características de cada organização, este tema também seja tomado com a importância destacada nesta resolução; 
- Tomar o tema da formação sindical e política como central em todo este esforço. Estimular e impulsionar a organização de cursos, seminários, palestras, para a formação dos dirigentes e ativistas das entidades. Estas atividades de formação, tanto devem buscar aprimorar a formação política e sindical dos ativistas e dirigentes, como poderão estar voltadas para o assunto específico da organização de base. Para isso buscaremos parceria com o ILAESE ou outros institutos que atuem nesta área;

- Adotar como base política para o desenvolvimento deste trabalho, a elaboração realizada no Seminário Nacional de novembro de 2010, sistematizada no texto apresentado a este Congresso sem prejuízo de outras elaborações e materiais que possam ser apresentados pelas entidades e movimentos.

Plano de ação

A CSP-Conlutas deve reafirmar a busca da unidade como um objetivo permanente para a defesa dos direitos e da melhoria das condições de vida da classe trabalhadora. Nesse sentido, não deve poupar esforços para construir mobilizações unitárias com todos os setores que se disponham, fazendo um chamado permanente às direções majoritárias do movimento para que rompam com o governo e as políticas contrárias aos interesses dos trabalhadores, somando-se à luta.

Da mesma forma, nossa Central reafirma a manutenção de iniciativas próprias, autonomia de atuação e defesa de seu programa. Dentre essas iniciativas, destaca-se o movimento que construiu o Espaço de Unidade de Ação e o apoio a todas as formas de lutas que os vários setores de nossa classe desenvolvem em resistência aos ataques dos governos e dos patrões. Assim considerando, o $1^{\circ}$ Congresso Nacional da CSP-Conlutas aprova uma série de eixos e bandeiras que compõem a nossa plataforma de reivindicações e plano de lutas balizado nas principais campanhas das categorias e movimentos dos trabalhadores, à serem desenvolvidos no próximo período.

Plataforma de reivindicações e bandeiras de luta:

- POR UM PLANO ECONÔMICO DOS TRABALHADORES 
(Aumento geral de salários e garantia de recomposição automática para evitar as perdas, salários dignos para todos, salário mínimo do DIEESE; pela redução e congelamento dos preços, tarifas públicas e aluguéis; estabilidade no emprego e fim da demissão imotivada; aplicação e ampliação da Convenção 158 da OIT, fim da informalidade do trabalho e emprego para todos e todas e unificação das campanhas salariais);

- REDUÇÃo DA JORNADA DE TRABALHO SEM REDUÇÃO SALARIAL- CONTRA AS PRIVATIZAÇÕES - DEFESA DO PATRIMÔNIO E DOS RECURSOS NATURAIS DO BRASIL

(Contra a privatização dos aeroportos, reestatização das empresas privatizadas; contra os leilões do petróleo, Petrobras e Correios 100\% estatal - Apoio às campanhas "Todo o petróleo tem de ser nosso" e "O minério tem de ser nosso");

- PElO DIREITO À MORADIA DIGNA/ TERRA PARA QUEM NELA TRABALHA - REFORMA AGRÁRIA JÁ

(Contra as remoções e os despejos, agravados com os mega eventos - Copa do Mundo e Olimpíadas / Em defesa da reforma agrária e condições dignas de trabalho no campo; fim do latifúndio e do agronegócio; aplicação de políticas públicas com apoio técnico e financiamento para o pequeno produtor rural / Reforma urbana com investimento público em habitação, sob controle dos trabalhadores);

- DEFESA DA APOSENTADORIA E DA PREVIDÊNCIA PÚBLICAS

(Fim do fator previdenciário / Contra a adoção de idade mínima e o fator 85-95, que mantém o sacrifício dos (as) trabalhadores (as) / Recomposição do valor das aposentadorias / Contra os fundos de aposentadoria complementar, pois significam a privatização da previdência);

- CONTRA OS CORTES DO ORÇAMENTO - DEFESA DO SERVIÇO PÚBLICO E DOS DIREITOS SOCIAIS DO POVO BRASILEIRO - COMBATE À CORRUPÇÃO

(Mais verba para saúde, educação, moradia, transpor te público e reforma agrária / Fim do superávit primário e suspensão do pagamento 
da dívida externa e interna aos grandes especuladores / Fim dos subsídios e isenções fiscais às grandes empresas / Expropriação dos bens e prisão para todos os corruptos e corruptores e estatização do sistema financeiro);

- EM DEFESA DA EDUCAÇÃO E DA SAÚdE PÚBLICAS (Aplicação imediata de $10 \%$ do PIB na educação publica / Implementação imediata do piso nacional dos professores, com 1/3 da jornada em atividade extraclasse / Mais verbas para a saúde pública; pelo fim da DRU - Desvinculação de Receitas da União e revogação da Lei de Responsabilidade Fiscal);

- $\quad$ EM DEFESA DOS (AS) SERVIDORES (AS) PÚBLICOS (AS)

(Valorizar os (as) servidores (as) públicos é valorizar o serviço público / Apoio às reivindicações dos (as) servidores (as) públicos (as) / Defesa do direito de negociação coletiva / Contra as restrições ao direito de greve, seja dos (as) trabalhadores (as) da iniciativa privada, seja do serviço público);

- NENHUM DIREITO A MENOS - CONTRA A PRECARIZAÇÃO DO TRABALHO

(Contra a flexibilização da CLT, em defesa e ampliação dos direitos trabalhistas e sociais / Contra a terceirização / Combate aos acidentes e ambientes insalubres no trabalho / Combate a todas as formas de trabalho escravo e em condições análogas à escravidão / Combate a todas as formas de assédio moral);

- CONTRA A CRIMINALIZAÇÃO DA POBREZA E DOS MOVIMENTOS SOCIAIS

(Em defesa do direito de lutar e dos dirigentes das lutas, presos e perseguidos; contra a aplicação do interdito proibitório nas ocupações e greves, em defesa do direito de greve, apuração dos crimes e punição dos assassinos dos trabalhadores rurais, chega de mortes nos conflitos sociais: direito de autodefesa das comunidades e movimentos sociais reprimidos / Pela reintegração de todos os dirigentes sindicais 
demitidos e estudantes expulsos das escolas, pela retirada de todos os processos administrativos de dirigentes sindicais e militantes estudantis / Lutar é um direito, não é crime);

- DESMILITARIZAÇÃO DAS POLÍCIAS MILITARES E CORPOS DE BOMBEIROS

(Vetar seu uso na repressão aos trabalhadores, comunidades pobres e movimentos populares / Defesa dos direitos humanos, pela prisão dos torturadores, mandantes, financiadores e colaboradores da ditadura militar, pela abertura de todos os arquivos do regime militar);

- CONTRA O NOVO CÓdIGO FLORESTAL/ EM DEFESA DO MEIO AMBIENTE

(Contra a construção de Belo Monte, a transposição do rio São Francisco e todas as práticas capitalistas que destroem as florestas, os rios, as matas, a fauna e a flora, defesa e respeito à demarcação das terras indígenas e quilombolas);

- CONTRA TODA FORMA DE DISCRIMINAÇÃO E OPRESSÃO

(Combate a toda forma de discriminação e opressão às mulheres, negros e homossexuais e demais setores oprimidos / Salário igual para trabalho igual, creches para as famílias trabalhadoras, pela criminalização da homofobia);

- ORGANIZAÇÃO SINDICAL LIVRE

(Direito à organização dos trabalhadores nos locais de trabalho, liberdade e autonomia sindical / Fim do imposto sindical)

- SOlIDARIEDADE E LUTA EM DEFESA DOS TRABALHADORES

(Pela unidade da luta internacional dos trabalhadores / Todo apoio à revolução árabe e à luta do povo sírio contra a ditadura de Assad / Todo apoio às lutas dos trabalhadores europeus contra os planos de austeridade / Fora as tropas brasileiras do Haiti / Nenhuma confiança no governo Dilma, governadores e prefeitos); 
- OPOSIÇÃO DE ESQUERDA AO GOVERNO DILMA POR UM GOVERNO DOS TRABALHADORES E POR UMA SOCIEDADE SOCIALISTA.

Campanhas centrais para o próximo período No Brasil, ainda é latente entre os trabalhadores a ilusão e apoio ao governo Dilma, que continua contando com o aval inestimável da maioria das direções sindicais, populares e estudantis às suas políticas. Os reflexos da crise econômica internacional se fazem presentes no país, com a desaceleração da economia e redução das expectativas de crescimento. Os governos e o patronato respondem preventivamente a essa situação com mais ataques aos direitos dos trabalhadores e criminalização das suas lutas e dirigentes. Os trabalhadores, no entanto reagem em várias frentes e as batalhas seguem em curso. Por isso, queremos apontar alguns eixos que deverão nortear a atividade da Central na organização dessas batalhas.

Unificação das lutas e fortalecimento da unidade de ação

Os patrões e os governos endurecem o jogo com os trabalhadores, negando as reivindicações das categorias e, no caso dos governos, acenando com reformas e projetos de lei que atacam direitos de nossa classe. O espaço de unidade de ação tem cumprido um papel importante na construção de ações unitárias, envolvendo os trabalhadores da ativa, aposentados e pensionistas, dos setores privado e público, movimentos populares e estudantis. Nossa Central buscará fortalecer esse espaço e construir todas as ações comuns que forem possíveis, sem abdicar de sua intervenção independente. Ganha importância a luta contra a reforma previdenciária que o governo Dilma vem fazendo de maneira fatiada, afetando mais fortemente os servidores públicos nesse momento.

Campanha Salarial dos Servidores Federais

O funcionalismo federal trava uma luta duríssima contra o Governo Dilma-PT em sua campanha salarial. O governo não só aplica o arrocho e congelamento salarial desde 2008 , como também vem realizando uma série de reformas que retiram direitos desses trabalhadores e que levam privatização à previdência (fundos de pensão) e aos hospitais universitários. O Fórum das entidades nacionais dos servidores federais já 
realizou uma semana de lutas em março e uma paralisação nacional em 25 de abril, como advertência ao governo pelo não avanço nas negociações. Agora, as entidades começam a discutir a possibilidade de uma Greve Geral dos SPF ainda para esse semestre e a CSP-Conlutas se coloca na linha de frente para ajudar nessa construção e buscar apoio e solidariedade do conjunto de suas entidades e organizações filiadas, para tentar garantir a vitória desse importante movimento.

Unificação das campanhas salariais do segundo semestre de 2012

Os petroleiros, bancários, metalúrgicos, trabalhadores dos Correios, do processamento de dados, eletricitários e outras categorias tem suas datas-base concentradas entre setembro e novembro. A CSP-Conlutas buscará unificar essas lutas em calendários e iniciativas comuns, como forma de pressionar os patrões e os trabalhadores alcançarem suas reivindicações.

Campanha contra os crimes da Copa do Mundo e as lutas do movimento popular:

A proximidade dos megaeventos como a Copa do Mundo de 2014 e a Olimpíada de 2016 no Rio de Janeiro desencadearam uma onda de ataques às comunidades, através de remoções forçadas e um processo de "higienização" social dos centros urbanos, para favorecer a especulação imobiliária. Do mesmo modo, os governos seguem aplicando uma política de despejos violentos em áreas ocupadas por trabalhadores sem teto, cujo símbolo mais dramático foi a expulsão de 9 mil pessoas de suas casas no bairro do Pinheirinho, São José dos Campos. Na esteira da resistência, o movimento popular organizado na Central, desenvolveu a campanha dos Novos Pinheirinhos, que, junto com a campanha Contra os crimes da Copa vem realizando uma série de ações de ocupação de terrenos e pressão sobre os órgãos públicos com intuito de exigir moradia digna para todas as famílias de sem teto. Nesse sentido, os enfrentamentos tendem a aumentar, sendo necessário fortalecer a resistência e garantir a participação ativa da CSP-Conlutas no Movimento Popular, em especial ocupações de terra e resistência aos despejos e a criminalização. A CSP-Conlutas contribuirá na organização do Plebiscito Nacional contra os crimes da Copa 
do Mundo, que ocorrerá no segundo semestre de 2012, ajudando na divulgação junto às entidades filiadas, para que se essas também se integrem ao plebiscito. Por isso, nossa Central entende como necessário uma vigorosa mobilização de todos os setores em apoio a essas lutas. Essas duas campanhas devem ser assumidas como tarefas de toda a Central e dos setores que organizamos para o próximo período.

Construir um grande ato nacional durante a realização da Rio+20 com todas as organizações que participarão da Cúpula dos Povos

Passados 20 anos da realização da Rio-92 (Eco-92 - Conferência da ONU que abordou o tema do meio ambiente e desenvolvimento) a situação ambiental do planeta em nada melhorou e as condições da humanidade são ainda piores que naquele momento. A Rio+20 vem com a propaganda do "capitalismo verde" e da construção de políticas de desenvolvimento sustentável, mas na verdade é mais um fórum internacional que reunirá os principais governantes do mundo para reafirmar seu sistema, onde não há lugar para a defesa do meio ambiente, dos povos originários e de condições dignas para o povo trabalhador.

Este encontro acontece no momento em que no Brasil o governo Dilma impõe as maiores barbaridades contra as populações pobres e agride o meio ambiente para construção de grandes obras para a Copa do Mundo, Olimpíadas e PAC

-Belo Monte, Jirau, Pecen e Suape são exemplos de como, ao capital, pouco importa as consequências de sua ganância em relação ao meio ambiente ou à superexploração da classe trabalhadora. Assim, nada esperamos desse evento, porque não passa de uma manifestação hipócrita dos governos burgueses, e sabemos que a melhora das condições ambientais só será possível com a destruição do capitalismo.

Neste contexto, nossa Central impulsionará uma campanha pela construção de uma grande manifestação no Rio de Janeiro combinando com a participação na Cúpula dos Povos (de 15 a 23 de junho), evento alternativo à Rio+20.

Derrotar a reforma sindical e trabalhista

Nesse momento está em discussão no Congresso Nacional a retomada das reformas sindical e trabalhista, através da PEC 369, 
que unifica vários projetos e possui três dimensões: dá poder de negociação para federações e centrais em substituição aos sindicatos, prevalência do negociado sobre o legislado e regulamenta o direito de greve, de maneira restritiva. A Central deve assumir essa como uma campanha fundamental no próximo período.

Campanha pelo direito à organização dos trabalhadores em seus locais de trabalho

A organização de base, em sentido amplo (nos locais de trabalho, moradia e nas escolas) foi o tema escolhido para esse $1^{\circ}$ Congresso da CSP-Conlutas, que deve aprofundar as medidas discutidas no Seminário Nacional que realizamos em novembro de 2011, cujos eixos são:

- Defesa do direito político dos trabalhadores a constituírem suas organizações de base nos locais de trabalho

- Inclusão, nas pautas de reivindicações das campanhas salariais dos sindicatos, do direito à organização no local de trabalho;

- Combate às perseguições e criminalização dos ativistas

- Fomentar as iniciativas institucionais pela regulamentação do direito à organização nos locais de trabalho, estreitando contato com a Ordem dos Advogados do Brasil, Ministério Público do Trabalho e ainda junto ao Poder Legislativo.

Campanha contra as privatizações

O PT se igualou ao PSDB também nessa matéria e através das PPPs e diversas manobras, como a abertura de capital das estatais, concessões da exploração das bacias do pré-sal, dentre outras, executa um plano ousado de privatizações, desnacionalizando setores estratégicos da economia como a exploração do petróleo e entregando as riquezas sob controle do estado ao capital privado nacional e internacional. A realidade é a mesma nos governos do PSDB como comprova a privatização da linha 4 do metrô de São Paulo, por exemplo. É urgente e necessário lançar uma ampla campanha contra as privatizações do governo Dilma e dos governos estaduais. 
Resolução sobre o trabalho da CSP-Conlutas com os aposentados

A CSP-Conlutas, apesar de minoritária no movimento sindical brasileiro e ainda pouco organizada no segmento de aposentados, deve manter uma politica constante de denúncia do governo e enfrentamento à politica de desmonte da Previdência. Por isso, o $1^{\circ}$ Congresso da CSP- Conlutas aprova as seguintes resoluções:

- Cada entidade filiada à CSP-Conlutas deve organizar os trabalhadores aposentados de sua base, criando um "Departamento de Aposentados" ou uma "Secretaria de Aposentados", vinculados ao próprio organismo sindical, mas com políticas específicas para esse segmento da classe;

- Para viabilizar a organização dos aposentados, é de suma importância que, tanto os sindicatos, como a própria CSP-Conlutas, tenham em suas instancias de direção membros responsáveis pela tarefa e que acompanhem a implementação da medida acima descrita, além de organizar a nossa intervenção nacional no setor;

- Manter a politica de trabalho unitário com a Fapesp (Federação dos Aposentados, Pensionistas e Idosos do Estado de São Paulo), a Cobap (Confederação Brasileira dos Aposentados e Pensionistas) e entidades dirigentes do movimento dos aposentados e outras federações estaduais;

- A CSP-Conlutas lançará, em unidade com outros setores combativos do movimento, uma ampla campanha em defesa da aposentadoria e da Previdência Publica que inclua os trabalhadores da ativa, os informais e os aposentados;

- De imediato, denunciar a chamada "desoneração da folha de pagamento das empresas", exigir minimamente o mesmo o reajuste do salário mínimo às aposentadorias e pensões e o fim do fator previdenciário, sem nenhum outro ataque para substitui-lo (como os fatores 105/95 ou 95/85); 
- Divulgar e lutar pela aprovação dos projetos de lei de interesse dos aposentados no Congresso Nacional, como o PL 4434/08, que atualiza os benefícios dos aposentados de acordo com o número de salários mínimos da época de sua concessão. Além disso, dois vetos presidenciais do governo Lula precisam ser votados: o do fim do fator previdenciário (2010) e o do reajuste de $16,67 \%$ para aposentados e pensionistas (2006);

- Sempre que possível, unificar as lutas dos servidores públicos aposentados com a dos demais trabalhadores aposentados pelo RGPS (Regime Geral da Previdência Social).

Resolução sobre os crimes cometidos pela ditadura militar

Em 31 de março de 2012 o golpe militar de 1964 fez 48 anos e a maioria dos crimes cometidos pelos agentes do Estado que atuaram de maneira ilegal não foram punidos. Estes crimes incluem perseguições e prisões ilegais, formação de quadrilha com grupos paramilitares, espancamentos, torturas, sequestros, estupros e assassinatos.

Em particular os trabalhadores que lutaram contra a ditadura, realizando movimentos grevistas e lutas de resistência que geraram a derrubada do regime autoritário, sofreram a prática persecutória, recorrente, de demissões, prisões arbitrárias, sequestros, compelimento à clandestinidade, torturas e monitoramentos ilícitos.

A sociedade brasileira exige fortemente a apuração e punição destes crimes, assim como exigiram as populações de outros países latino-americanos, como o Chile, Uruguai e Argentina. A verdade é que o Brasil é o país mais atrasado da América Latina em punir repressores da ditadura.

O governo Dilma tenta não realizar a punição dos responsáveis e a reparação das vítimas, alegando que a Lei da Anistia de 1979 anistiou os presos, torturados, mortos e também os torturadores e assassinos. Apoia-se na posição do Supremo Tribunal Federal que decidiu em 2008 que a Lei da Anistia impediria julgamentos de atos praticados durante o regime militar.

Mas crimes de lesa-humanidade - tais como a tortura são imprescritíveis e impassíveis de anistia, até mesmo a legislação brasileira 
determina que crimes como sequestros não possam prescrever sem a localização dos sequestrados. Porém, em virtude da pressão social, em 21 de setembro de 2011 o governo aprovou na Câmara dos Deputados um projeto que cria a Comissão da Verdade para investigar estes crimes cometidos pelo Estado durante o período de 1946 a 1988.

Esta comissão nasceu com muitas deformações. Uma delas é que não terá independência do governo, todos os membros serão nomeados pela presidenta Dilma. Além disso, não terá meios legais e materiais para investigar a fundo os crimes cometidos e, o pior, tem por objetivo apenas investigar e não aplicar punições aos criminosos da ditadura.

A existência dessa Comissão da Verdade só tem sentido se tiver como resultado a identificação dos agentes do Estado que participaram da repressão política e sua responsabilização, julgamento e punição exemplar. Porém, esta Comissão não saiu do papel e ninguém nem sabe quem serão seus representantes.

Uma política de Direitos Humanos do Estado impõe que este assuma suas responsabilidades e que invista na diminuição dos efeitos do legado da violência do regime autoritário, sendo determinante que se valorize o direito à resistência dos povos contra a opressão.

Portanto, o $1^{\circ}$ Congresso da CSP-Conlutas resolve:

- Fortalecer a campanha nacional de ANISTIA A TODOS OS PRESOS E PERSERGUIDOS DURANTE A DITADURA MILITAR A a CAMPANHA PELA FORMAÇÃO DE UMA VERDADEIRA COMISSÃO DA VERDADE QUE INVESTIGUE E PUNA OS CRIMINOSOS DA DITADURA. Engajar-se com todos os sindicatos e movimentos em atos e manifestações;

- Exigir que a COMISSÃO DA VERDADE seja independente do governo, com uma equipe que não seja questionada pelos movimentos sociais; com orçamento destinado à execução desse trabalho e possa realizar a apuração dos crimes cometidos pelos agentes do Estado para julgar e punir estes criminosos; 
- Exigir que a abrangência da COMISSÂO DA VERDADE atinja, não somente os agentes que diretamente prenderam, torturaram e mataram, mas também que se investigue e puna os seus "patrocinadores", aqueles que apoiaram e financiaram material e politicamente estas ações de exceção;

- Exigir que a COMISSÃO DA VERDADE revele que houve no país, de fato, uma LUTA DE RESISTÊNCIA a uma ditadura autoritária e sanguinária e não simplesmente atos terroristas dos resistentes;

- Exigir também que todos que foram perseguidos e presos pela ditadura sofreram torturas, prisões arbitrárias, sequestros, compelimento à clandestinidade e ao exílio, demissões e transferências por razões políticas, banimentos, expurgos estudantis e monitoramento ilícitos sejam incluídos nos programas de reparação material, incluindo restituições de direitos, compensações financeiras e disponibilização de serviços de educação, saúde e moradia;

- Exigir também a mudança de nomes de espaços públicos dados aos criminosos do Estado, o estabelecimento de dias de comemoração e a construção de museus, parques e locais de memória dos que lutaram contra a ditadura. Formar uma Comissão que coordene e implemente as atividades, a partir do comitê, no Brasil todo.

Resolução contra a criminalização dos mov mentos sociais e da pobreza

O último período vem marcado pelo aprofundamento da crise econômica mundial. Os governos burgueses, por sua vez, respondem à crise com amplos ataques às conquistas e direitos dos trabalhadores para manter a taxa de lucro dos patrões e aprofundar a exploração capitalista. O Brasil também sofre as consequências desse marco histórico. Ainda que os efeitos da crise mundial não se manifestem aqui no mesmo grau que na Europa, o governo Dilma Rousseff-PT antecipa uma série de medidas que surrupiam direitos e pioram a vida dos trabalhadores e da juventude. Os governos burgueses tam- 
bém agem de forma violenta contra os movimentos de resistência de nossa classe e, da mesma forma que na Europa, a escalada de violência e o braço armado do Estado contra as organizações da classe trabalhadora em nosso país se expressa em todas as ações, seja na cidade ou no campo, nos processos sindicais ou do movimento popular e estudantil.

A política bonapartista e criminosa dos governos se apresenta com medidas de "arapongagem" e ações terroristas, como o atentado à sede do SINTUSP. Ou nas ações de repressão violenta praticadas pela Polícia Militar no despejo das famílias do bairro Pinheirinho, em São José dos Campos. Mas também na Cracolândia e nas lutas dos estudantes contra o aumento das passagens, não excetuando sequer as greves de policiais, como nos casos de Bahia e Rio de Janeiro, que foram reprimidas com a prisão de lideranças e proibição do movimento. Avançam ainda com medidas como as ações de ilegalidade das greves, interditos proibitórios, indiciamento no Código Penal e prisão de lideranças sindicais e populares.

Considerando a tendência de agudização da crise em nosso país, esses governos, junto com os patrões, seguirão adotando medidas duras contra os direitos da população pobre e trabalhadora. Nesse sentido, a repressão e a criminalização dos movimentos são parte de uma estratégia dos governos, em todas as escalas, ou seja, federal, estadual e municipal, no sentido de inibir as mobilizações da classe trabalhadora.

Diante dessa situação, o $1^{\circ}$ Congresso Nacional da CSP-Conlutas resolve:

- Impulsionar uma forte e permanente Campanha Nacional Contra a Criminalização dos Movimentos Sociais e da Pobreza, utilizando amplo material de divulgação, como manifesto contra os crimes do Estado Burguês, cartazes, folders e mídia audiovisual;

- Organizar ações de denúncia permanente contra esses crimes, desde os movimentos citados nessa resolução, mas avançando essa denúncia aos crimes nas obras da Copa do Mundo, PAC e outras. Contra a militarização dos canteiros de obras do 
PAC e da copa e olimpíadas, e a repressão e criminalização da luta dos operários. Pelo direito de greve;

- Propor ações conjuntas com os organismos nacionais e internacionais de Direitos Humanos que deem visibilidade à campanha de denúncia contra esses crimes, utilizando todos os espaços disponíveis: audiências públicas nos parlamentos municipais, estaduais e federal, seminários, debates, mesas redondas e atos públicos;

- Orientar todas as entidades e movimentos da CSPConlutas, incluindo a Secretaria Executiva Nacional e as Secretarias Estaduais e Regionais, para que mantenha ponto permanente em suas pautas de reunião sobre esse tema, organizando a solidariedade e a defesa dos movimentos atacados pela repressão dos governos e da patronal;

- Por uma campanha contra a repressão na USP e reintegração dos estudantes expulsos, trabalhadores demitidos por motivação política. Pela retirada dos processos contra todos os indiciados criminalmente na justiça burguesa.

Reforma agrária: bandeira estratégica da CSP-Conlutas

O CONCLAT aprovou uma importante resolução sobre a questão agrária no Brasil, identificando a histórica concentração fundiária, o compromisso dos governos do PT com o agronegócio, o favorecimento do grande capital no campo (créditos, pesquisas, infra-estruturas, impunidade) e sua conivência com graves crimes ambientais, o descaso com os assentamentos rurais e com as populações camponesas, a criminalização de lideranças, os frequentes assassinatos.

A CSP-Conlutas não é apenas apoiadora de movimentos rurais, mas é parte intrínseca da luta contra o latifúndio, contra os monopólios e favor da democratização da terra e do uso racional e ecológico dos recursos naturais. Nesse contexto, o $1^{\circ}$ Congresso da CSP-Conlutas reafirma o eixo de ação política na questão agrária, já aprovada em 
fóruns anteriores, e referenda as resoluções do CONCLAT no sentido de criar as condições políticas e materiais para a sua aplicabilidade.

Reforma urbana: luta de toda classe trabalhadora

Nossa participação na resistência frente à recente violência no despejo do Pinheirinho, São José dos Campos, marca um evidente compromisso da CSP-Conlutas com a moradia, com o saneamento, com a saúde, com a educação, com os direitos humanos, com a preservação da vida, com a partilha da terra. Sindicalizados ou não, os trabalhadores brasileiros são alijados de direitos básicos: casa, trabalho, comida. A especulação imobiliária nas cidades médias e nas metrópoles chega a níveis extremos. Os eventos esportivos vindouros (Copa e Olimpíadas) fazem aumentar os lucros das grandes imobiliárias e empreiteiras, o desalojamento de milhares de famílias, a violência contra o povo pobre, o compromisso de governantes e do poder judiciário com os donos do capital.

A CSP-Conlutas, ciente do necessário aprofundamento desse tema, desenvolvera iniciativas para a conscientização de todas as entidades filiadas e suas lideranças, populares ou sindicais, com objetivo de estabelecer o compromisso permanente com a Reforma Urbana em nosso país.

Juventude e movimento estudantil

A juventude tem um reconhecido potencial contestatório, e cabe às organizações dos trabalhadores oferecer uma proposta estratégica e um abrigo para a juventude proletária e excluída, justamente sua porção mais explorada.

A juventude sindicalizada ou inserida formalmente no mundo do trabalho já encontra sua identidade com a sua categoria profissional e com os eixos de luta da classe trabalhadora.

A juventude organizada no movimento estudantil não constitui uma classe por si, já que não ocupa uma posição própria no sistema de relações de produção, no mundo do trabalho.

A juventude dos bairros, em particular das periferias, apresenta vínculos indiretos ou muito frágeis com o processo produtivo e os meios de produção. 
Mas identifica-se com o proletariado principalmente por sua origem e por suas condições de vida: habitação, acesso aos recursos tecnológicos e aos aparelhos públicos, como cultura, saúde e educação.

A propaganda capitalista acena para a juventude com algumas possibilidades, mas com nenhuma alternativa, a não ser adequar-se ao sistema para garantir sua sobrevivência. Fatalmente, Ihes restará o papel de explorados.

Em geral, os primeiros confrontos dos jovens com o sistema se dá com a negação dos valores burgueses que buscam enquadrá-los como explorados.

Estes primeiros confrontos com a família e com a sociedade são fragmentos de rupturas sociais, da não aceitação de todas as regras, mesmo que de forma simbólica, limitada, individual e temporária. É a primeira experiência enquanto agente ativo na definição de valores e conceitos na sociedade.

É desta rebeldia e da busca por uma nova identidade, e não a de sujeito explorado, que sai a energia que constrói movimentos culturais como o hip-hop e o grafite.

Por mais explosiva que seja sua reação à tendência de adaptação à lógica capitalista, sem uma perspectiva revolucionária a juventude é inevitavelmente tragada pelo sistema.

Aqui entra a importância de um projeto político que organize e apresente um programa de ruptura para a juventude.

As escolas são o principal ponto de encontro da juventude na periferia. Os Grêmios podem tornar-se um centro de referência de organização para os jovens da região, que podem organizar palestras, oficinas, festivais de música e mostras de filmes e teatro, atividades que seriam parte de um processo mais amplo de formação política.

Esta referência é decisiva nos momentos de mobilização, como nas campanhas pelo passe-livre.

Nos movimentos populares do campo, e nas cidades de forma mais limitada, na medida em que consolidamos de ocupações e processos de autogestão, através das áreas sob o controle dos trabalhadores, 
oferecemos à juventude pobre e ao povo uma perspectiva de organização, luta e sobrevivência que os meios tradicionais não são capazes de fazer.

E oferecemos à universidade e aos intelectuais uma perspectiva alternativa de intervenção: agrônomos, veterinários, biólogos, geógrafos, educadores, nutricionistas e comunicadores que se vincularão aos processos de produção, comunicação e reocupação do campo; engenheiros, arquitetos, químicos, médicos e artistas que se vincularão à processos similares na cidade, que finalmente estariam integrados e não mais divididos nessa dicotomia "campo e cidade".

Isso, além de potencializar nossas experiências, pode retornar e criar dentro das universidades um vigoroso movimento de estudantes e intelectuais vinculados diretamente à luta socialista, tanto na teoria como na prática.

Sobre a importância da aliança operária estudantil

A juventude tem sido protagonista nas mobilizações e nas revoluções que estão ocorrendo no mundo todo.

É assim no norte da África e no Oriente Médio, na luta contra as ditaduras; na Europa, nas greves, mobilizações e ocupações contra os efeitos da crise econômica; e também na América Latina, onde o Chile e na Colômbia o movimento estudantil tomou as ruas num Ascenso de massas contra a precarização da educação.

Em toda a sua história o movimento estudantil brasileiro sempre esteve engajado em campanhas gerais do movimento social e foi aliado dos trabalhadores nos principais enfrentamentos da luta de classes, como por exemplo, na luta contra a ditadura militar, na histórica campanha do Petróleo é nosso, Fora Collor, etc.

O policlassismo do movimento estudantil coloca a necessidade de ganhar uma parcela significativa dos jovens estudantes para se aliar às lutas dos trabalhadores e de disputar a enorme força democrática que tem os estudantes quando se mobilizam para uma aliança com a classe trabalhadora, única que pode de fato transformar a sociedade de conjunto. O movimento estudantil, como comprovado pela história, pode ser a faísca que impulsione a explosão de revoltas sociais e mobilizações operárias. 
É nessa expectativa que reafirmamos o caráter da CSP-Conlutas - Central Sindical e Popular e estudantil, que sem negar em nenhum momento a centralidade da classe trabalhadora como sujeito fundamental da transformação da sociedade, teve a ousadia de testar uma forma de organização inédita em nosso país, onde trabalhadores e juventude compõe organicamente uma mesma central.

Nas principais lutas que ocorreram nesses primeiros dois anos da central, a organização em conjunto de trabalhadores e estudantes se mostrou um caminho acertado para potencializar as lutas. Foi assim na luta dos Bombeiros no Rio de Janeiro, nas greves operárias da construção civil, na campanha de defesa do Pinheirinho e na campanha e Plebiscito Popular pelos $10 \%$ do PIB para educação pública já.

Nossa Central precisa ser conhecida como aquela que leva os estudantes para a porta das fábricas, para os canteiros de obras, para as ocupações e para as tribos indígenas e que leva os operários, os sem teto, os sem terras e os quilombolas para dentro das universidades e escolas para as lutas em conjunto com o movimento estudantil.

Acreditamos que a aliança operário-estudantil é estratégica para nossa luta de transformação da sociedade e a CSP-Conlutas deve continuar sendo a referência desta experiência em nosso país. Por isso, está colocada para nossa Central a grande tarefa de aprofundar esta relação e potencializar as lutas conjuntas dos trabalhadores, estudantes e movimento popular.

Resolução sobre a questão de raça e classe Considerando:

- Que na conjuntura atual estão colocados mais ataques neoliberais, perdas de direitos para a classe trabalhadora e o crescimento das mazelas do capitalismo, em especial à população negra, parte da base da pirâmide social, a maioria da população brasileira e a segunda fora da África; 
- Os ataques são efetuados contra toda a classe trabalhadora, mas os negros são os mais atingidos pela precarização do trabalho, desemprego e os que mais sofrem com o sucateamento dos serviços de educação e saúde. A falta de moradia, saneamento básico, aumento da violência no cotidiano das cidades e no campo são frutos da violência praticada pelo Estado. Este deveria ser o principal responsável por políticas publicas de reparação, ações afirmativas e cotas, com objetivo de reduzir as desigualdades raciais e sociais. Essas desigualdades são aprofundadas na consciência da classe trabalhadora, pela política imposta hipocritamente pelo Estado do mito da democracia racial;

- É preciso aprofundar a unidade e as ações de combate, na luta direta contra o racismo, o machismo, a homofobia, a exploração e a opressão. Fortalecendo dessa forma a consigna de Raça e Classe na consciência da classe trabalhadora, através das organizações sindicais e dos movimentos de luta contra a opressão capitalista. (negros, negras, mulheres, lgbt, estudantil, popular e cultural).

O $1^{\circ}$ Congresso da CSP-Conlutas resolve:

- Lutar por salário igual para trabalho igual, para negros e brancos, homens e mulheres e contra a perda de direitos sociais e trabalhistas;

- Defender a valorização dos servidores públicos, e defesa dos serviços públicos de qualidade para a população negra;

- Defesa da saúde e educação 100\% estatal, publicas e antirracistas;

- Pela aplicação da lei 10.639 e dos $10 \%$ do PIB para educação publica já;

- Contra o PROUNI e REUNI; por uma universidade $100 \%$ estatal e pública, com no mínimo $25 \%$ de cotas raciais; 
- Em defesa do transporte publico, de qualidade e com tarifas populares;

- Defesa intransigente das trabalhadoras (os) que sofrem com Assedio Moral, Racial e Sexual, fruto das mazelas do capitalismo e do racismo, do machismo e da homofobia;

- Regulamentação das terras de Quilombos e Indígenas! - Em defesa da titulação das terras de quilombos, indígenas; pela manutenção do decreto 4887/03;

- Contra a criminalização dos movimentos sindicais, sociais e da pobreza, fim da intolerância contra as religiões;

- Defender uma política de estado pela construção de moradia digna para as negras e os negros;

- Pela valorização da cultura negra e popular das periferias e do campo/quilombolas e da cidade/juventude negra;

- Todo apoio e participação em espaços e movimentos de frente única de luta e combate contra o racismo independente dos governos e patrões;

- Incentivar a criação dos setoriais de negros nas CSP-Conlutas estaduais;

- Incentivar a criação das Secretarias de Combate a Discriminação e Opressão.

Resolução sobre as mulheres trabalhadoras

Lutar contra o machismo e a exploração, Unir a classe trabalhadora e fortalecer o trabalho de base

A crise econômica mundial hoje atinge com mais força o continente Europeu. O desemprego, corte de salários e flexibilização de direitos formam a receita do capitalismo para resolver suas crises: jogá-la nas costas dos trabalhadores. E, nesse processo, supeexploram os 
setores oprimidos. Utilizam as ideologias machistas, racistas, homofóbicas e xenófobas para ampliar a divisão da classe. Por outro lado, os trabalhadores resistem, com grandes protestos europeus contra os planos de austeridades e contra os governos, e nos países do norte da África e Oriente Médio, milhares saem às ruas contra ditaduras e as péssimas condições de vida. As mulheres estão presentes nessas lutas com destaque.

No Brasil, a crise ainda não tem afetado o país do mesmo modo que na Europa e EUA, mas mesmo assim o governo Dilma retirou mais de $\mathrm{R} \$ 100$ bilhões do orçamento das áreas sociais, privatizou aeroportos e a previdência dos servidores públicos e promove isenção fiscal aos grandes empresários, enquanto os trabalhadores pagam altas taxas juros. Para concretizar a realização da Copa do Mundo e das Olimpíadas, o governo vem desenvolvendo políticas e leis que preveem desocupações de áreas de moradia e aumenta a criminalização dos trabalhadores. As greves nas obras da copa demonstram a resistência dos trabalhadores às terríveis condições de trabalho. O episódio do Pinheirinho é um exemplo de como esses megaeventos produzem desastres à vida da população pobre.

Em relação às mulheres, a promessa de construção de 6427 novas creches não deverá ser cumprida, já que em 2011 nenhuma nova foi entregue pelo governo federal. Os programas de combate à violência tiveram seu financiamento reduzido por conta dos cortes no orçamento. O projeto Rede Cegonha e a MP 557/2011, reduziu a preocupação com a saúde da mulher à maternidade, deixando de lado a sua integralidade, e a criação de um cadastro de grávida atua contra a bandeira histórica do movimento pela legalização ao aborto. Aliás, Dilma se comprometeu com os setores conservadores, na "Carta ao povo de Deus”, a não avançar na legalização do aborto em seu governo.

Muitas trabalhadoras e trabalhadores acreditam que com Dilma podem mudar sua situação, mas a experiência de 16 meses de governo demonstra que não basta ser mulher, é preciso ter um programa que defenda a classe. O PT optou por governar para os banqueiros e empresários, atendendo a interesses que não podem ser 
conciliados aos das trabalhadoras. Por isso, Dilma não representa as mulheres trabalhadoras.

As mulheres são metade da classe trabalhadora brasileira (46\%). Elas são a maioria dos trabalhadores da Administração Pública, tem presença significativa nas indústrias, e nos setores considerados masculinos, como metalurgia, mineração e construção civil, a contratação de mulheres vem crescendo sensivelmente nos últimos 10 anos.

Essa ocupação "feminina", embora muito importante, é resultante dos processos de reestruturação produtiva e vem acompanhada de precarização das condições de trabalho que afeta toda a classe e as mulheres em particular. Elas estão localizadas nos setores menos remunerados e são a maioria entre os terceirizados. Ganham em média até $33 \%$ menos que um homem para uma mesma função. Essa diferença cresce quando falamos das mulheres negras.

O capitalismo se apoia no machismo para pagar menores salários e com isso regular o valor global da mão- de-obra, abrindo espaço para pagar menos também aos homens. $O$ trabalho doméstico culturalmente reconhecido como tarefa da mulher, desobriga o estado e os patrões de garantirem creches, lavanderias, restaurantes públicos. A mulher trabalhadora acumula um dia a mais de trabalho por semana em virtude da dupla jornada.

A falta de creches é o principal motivo para que as mulheres não consigam emprego ou permaneçam nele. A violência mata 10 a cada dia, mas não se resume aos crimes bárbaros, está na sutileza da piada que por vezes se transforma em assédio moral e sexual.

Essa realidade impõe desafios à organização do movimento sindical e popular em defesa dos direitos da classe trabalhadora. É preciso incorporar as demandas das mulheres trabalhadoras como parte da luta e atuação cotidiana do movimento sindical e popular. Isso é preciso para unificar a classe e aproveitar o potencial de organização das muIheres. É preciso um combate cotidiano ao machismo para incorporar mais mulheres e fortalecer a luta dos trabalhadores. É fundamental a unidade entre homens e mulheres trabalhadores. 
Por tudo isso e de acordo com resolução do I Encontro de Mulheres, realizado no dia 27 de abril, o $1^{\circ}$ Congresso Nacional da CSP-Conlutas, aprova as seguintes resoluções:

- Dilma não representa as mulheres trabalhadoras;

- A luta das mulheres só pode ser vitoriosa em unidade com os homens trabalhadores, de forma independente dos governos e patrões;

Principais bandeiras:

- Aumento geral dos salários. Salário Igual para Trabalho Igual!

- Garantia de atenção integral à gestante no parto e pré-natal;

- Licença-maternidade de 6 meses sem isenção fiscal, para todas as trabalhadoras e estudantes, rumo a um ano!

- Reconhecimento do atestado de acompanhamento dos filhos como abono de dias ao trabalho!

- Creches em tempo integral, gratuitas e de qualidade para todos os filhos da classe trabalhadora!

- Anticoncepcionais para não abortar, aborto legal, seguro e gratuito para não morrer!

- Revogação imediata da MP 557/2011, que criminaliza as muIheres!

- Pela autonomia sobre o próprio corpo, contra a exigência de autorização do marido para realização de "ligadura".

- Fim da Violência contra a mulher! Aplicação e Ampliação da Lei Maria da Penha! Punição dos Agressores, construção de casas-abrigo! 
- Cotas raciais nas universidades;

- Criminalização da Homofobia;

- Fim da terceirização que afeta principalmente as mulheres;

- Em defesa da previdência pública e das mulheres aposentadas.

Campanhas Políticas:

- Reafirmar a inclusão das datas históricas das lutas das mulheres no calendário de atividades da Central: o dia 08 de março - dia internacional de luta das mulheres trabalhadoras; 25 de julho - dia latino-americano da mulher negra; 28 de setembro - dia latino americano de luta pela legalização e descriminalização do aborto; 25 de novembro - dia latino americano de luta contra a violência às mulheres;

- Fortalecer as campanhas que a CSP-Conlutas vem desenvolvendo, como a "Trabalho Igual, Salário Igual", e a "Campanha Nacional por Creches". Essas campanhas devem ser encaradas como o esforço para colocar as mulheres trabalhadoras em movimento e como uma forma de incorporar cotidianamente as respostas políticas em relação às consequências da exploração e da opressão;

- Construção de uma campanha nacional contra a Violência à Mulher;

Medidas Organizativas:

- Qualquer organização que se pretende a fortalecer o movimento de massas na perspectiva de dar protagonismo às lutas e necessidades reais da classe trabalhadora precisa dar centralidade política e organizativa aos temas relacionados às lutas das mulheres, por isso defendemos: 
- Criação de Secretarias de Mulheres nos Sindicatos;

- Cotas para as mulheres nas diretorias, respeitando percentual de mulheres em cada categoria e incorporando as mulheres negras, como instrumento de promoção das mulheres, de formação de dirigentes sindicais, como o esforço para refletir as políticas das mulheres e para criar identificação das trabalhadoras da base com suas direções;

- Desenvolvimento de organizações por local de trabalho e ClPAS, estimulando a participação das mulheres, sendo os olhos e ouvidos das direções sindicais sobre a realidade da mulher trabalhadora.

- Realizar Campanhas de sindicalização voltada às mulheres;

- Realização de Encontros de Mulheres para deliberar sobre as pautas das mulheres a serem incorporadas na luta cotidiana;

- Garantia de creches em todas as atividades dos sindicatos e da Central, para que a responsabilidade com os filhos não seja o impeditivo para a participação das mulheres nas atividades.

- Cursos e palestras para a categoria e diretoria, como forma de educação política e vigilância constante às posturas machistas que ocorrem no interior do movimento sindical.

- Avançar e discutir no movimento popular como desenvolver mecanismos para ampliação da participação das mulheres, com a criação de espaços específicos que possam debater a realidade dessas trabalhadoras, encontros de mulheres nas ocupações, reuniões periódicas para discutir a demanda por creche, o combate à violência doméstica, etc.

- Realizar um novo encontro de mulheres, com maior tempo, que dê conta de aprofundar temas relacionados à terceirização, mulheres deficientes, LBGT, aposentadas entre outros. 
- As políticas e ações aqui apresentadas atuam no sentido de fazer agitação política sobre as mulheres trabalhadoras para ganha-las para a luta classista, tarefa fundamental para unir a classe trabalhadora e impor uma derrota aos patrões e governos, fortalecendo a luta por uma sociedade mais justa e igualitária, uma sociedade socialista.

Sobre as questões relativas aos LGBT's

O $1^{\circ}$ Congresso da CSP-Conlutas reafirma a importância da construção da Central como ferramenta de luta de combate contra as opressões, como a homofobia.

É fundamental aliar esta luta ao processo de reorganização da classe trabalhadora em curso em nosso país. Nesse sentido, é necessário que a organização do trabalho político voltado para a luta dos homossexuais aconteça a partir do trabalho de base nos locais de trabalho e estudo, assim como nos movimentos populares.

Neste Congresso, além dos homossexuais e transexuais do movimento estudantil, essencialmente os que estão organizados na ANEL, registra-se a presença do movimento sindical e, em especial, do movimento popular.

Por tudo isso, o $1^{\circ}$ Congresso da CSP-Conlutas resolve:

- Lutar por políticas de saúde da mulher lésbica e de pessoas transexualizadas;

- Construir de uma cartilha LGBT focando o movimento sindical e popular para fortalecer o trabalho de base;

- Participar da III Marcha contra a homofobia em Brasília em Maio de 2012;

- Construir uma intervenção qualificada nas Paradas do OrguIho LGBT;

- Organizar nas bases filiadas na CSP-Conlutas palestras referentes ao dia 28 de junho, resgatando o dia de luta pelo Orgulho Gay; 
- Construir o I Encontro Nacional do Setorial LGBT da CSP-Conlutas;

- Apoiar a despatologização da transexualidade;

- Lutar pela Garantia do nome social nos espaços públicos e de trabalho - Campanha de acesso universal a lei de alteração de nome civil, e sugerir a supressão de sexo e gênero em alguns documentos de identificação.

- Campanha pela União Civil e contra a criação de um "terceiro banheiro" para indivíduos LGBTs;

- Construir uma ampla campanha em defesa do Estado Laico.

\section{Tema 4 - Estatutos e Direção}

\section{ESTATUTOS}

Redação final aprovada após o debate das propostas de alterações:

\section{Capítulo I. Da transformação, da denominação, da natureza jurídica, da duração, das sedes e sub-sedes}

Artigo $1^{\circ}$ - A CENTRAL SINDICAL E POPULAR/Con-

lutas, também identificada pela sigla CSP-CONLUTAS, constituída a partir do Congresso da Classe Trabalhadora - Conclat - realizado em Santos/SP e ratificada nesta As-sembleia Geral Extraordinária ocorrida no dia vinte e quatro de julho do ano de dois mil e dez, no SINDSPREV/RJ, localizado na Rua Joaquim Silva, 98-A, Rio de Janeiro/ RJ, sucessora da Associação Coordenação Nacional de Lutas, originalmente constituída em 15 de dezembro de 2005, em Brasília/DF, e da Coordenação Nacional de Lutas/Conlutas, é uma entidade civil devidamente registrada, com personalidade jurídica de direito privado, natureza jurídica de central sindical, popular e de classe, sem fins lu- 
crativos e de duração indeterminada, com base territorial e representatividade em todo o território nacional, com sede e domicílio na Cidade de São Paulo/SP, à Praça Padre Manoel da Nóbrega, 36 - 6. ${ }^{\circ}$ andar, Sé - CEP 01015-010.

Parágrafo primeiro - A CSP-CONLUTAS tem personalidade jurídica própria e distinta das entidades a ela filiadas e não responde pelos atos praticados por seus filiados.

Parágrafo segundo - A CSP-CONLUTAS poderá estabelecer e manter em funcionamento sub-sedes nos estados e regiões do país.

Artigo $2^{\circ}$ - A CSP-CONLUTAS é entidade de caráter classista que se constitui como instrumento para a defesa das reivindicações, direitos e interesses imediatos e históricos da classe trabalhadora em seu conjunto, consubstanciados em seu programa.

Parágrafo primeiro - A CSP-CONLUTAS busca agrupar em seu interior as trabalhadoras e os trabalhadores organizados nos sindicatos, as organizações de trabalhadores desempregados e desempregadas, dos aposentados e aposentadas, os diferentes movimentos populares que organizam trabalhadores e trabalhadoras da cidade e do campo, as organizações e movimentos que lutam contra toda forma de discriminação e opressão e as organizações estudantis que decidirem participar das lutas da classe trabalhadora.

Parágrafo segundo - Sempre que no presente Estatuto for usada a expressão "trabalhadores e trabalhadoras", estará se referindo a todo o conjunto de setores, entidades e organizações referidas no parágrafo anterior. A expressão "Central" também será utilizada para designar a entidade ora constituída.

\section{Capítulo II. Do programa e dos objetivos}

Artigo $3^{\circ}-\mathrm{O}$ programa da Central deverá ser aprovado e só poderá ser alterado no Congresso Nacional da Central, sempre com vistas ao cumprimento dos objetivos da entidade. 
Parágrafo único - A concretização e atualização do programa referido no caput, para cada momento da luta de classes, poderá ser feita por deliberação da Coordenação Nacional da CSP-CONLUTAS.

Artigo $4^{\circ}$ - A CSP-CONLUTAS enquanto instrumento para a defesa de todas as reivindicações e demandas dos trabalhadores e trabalhadoras e das organizações a ela filiadas, tem como objetivos:

Parágrafo primeiro - Organizar e mobilizar os trabalhadores e trabalhadoras sempre no sentido de defesa dos seus direitos, interesses e prerrogativas.

Parágrafo segundo - Lutar por melhores condições de vida e trabalho.

Parágrafo terceiro - Lutar em defesa dos interesses históricos da classe trabalhadora, tendo como meta o fim de toda forma de exploração e opressão, sempre na perspectiva de uma sociedade socialista, governada pelos próprios trabalhadores e trabalhadoras.

Parágrafo quarto - Representar, com autonomia e independência, nas esferas política, administrativa e judicial, perante quaisquer órgãos da Administração Pública, dos Poderes constituídos e da sociedade, em qualquer instância, os interesses coletivos e individuais dos trabaIhadores e trabalhadoras, em matéria de direito individual, individual homogêneo, coletivo ou difuso.

Parágrafo quinto - Participar, mediante autorização dos filiados, de negociações coletivas nacionais, estaduais, regionais ou setoriais, pugnando pela defesa dos interesses dos seus representados, somente podendo firmar instrumentos decorrentes com expressa autorização dos mesmos.

Parágrafo sexto - Exercer a representação dos trabalhadores e trabalhadoras, por meio das entidades e organizações a ela filiadas.

\section{Capítulo III. DOS PRINCÍPIOS. Artigo $5^{\circ}-$ São princípios basilares da CSP-CONLUTAS.}

Parágrafo primeiro - A independência de classe. I) A atuação da CSP-CONLUTAS deverá basear-se no pressuposto de que a 
libertação dos trabalhadores e trabalhadoras será obra dos próprios trabalhadores e trabalhadoras. II) Para não fugir de seus objetivos a CSP-CONLUTAS deve se pautar pela mais completa independência política, financeira e administrativa em relação à classe empresarial, à burguesia classicamente considerada, aos governos e ao Estado. III) É incompatível o recebimento de quaisquer recursos financeiros oriundos da União, dos Estados, dos Municípios, de ONGs ou de empresários. IV) É incompatível a ocupação, pelos dirigentes da Central, de funções públicas ou cargos em tarefa de direção em qualquer instância governamental.

Parágrafo segundo - A construção da unidade, como valor estratégico, na luta dos trabalhadores e trabalhadoras. I) A CSP-CONLUTAS defenderá e atuará para assegurar a unidade dos trabalhadores e trabalhadoras na luta por seus direitos e interesses. II) A unidade é um meio fundamental para fortalecer os trabalhadores nas suas lutas. III) A unidade de ação com outros setores para além da CSP-CONLUTAS não se contrapõe ou se sobrepõe à independência política da Central.

Parágrafo terceiro - A defesa da ação direta. I) A CSP- CONLUTAS defende a mobilização coletiva e a ação direta dos trabalhadores e trabalhadoras como formas privilegiadas de luta; II) A CSP-CONLUTAS poderá se utilizar de outras formas de luta como a atuação no parlamento ou a luta jurídica, as negociações e acordos que forem de interesse da classe trabalhadora, sempre e quando se fizerem necessários e forem aprovados na base; III) Todas as demais formas de atuação dos trabalhadores e trabalhadoras deverão estar subordinadas à sua ação coletiva, à sua mobilização, pois essa é a principal garantia de vitória da classe trabalhadora.

Parágrafo quarto - A autonomia frente aos partidos políticos. I) A Central, sendo uma organização de natureza sindical, popular e de classe, sem caráter partidário, é autônoma frente aos partidos políticos, o que significa que todas as suas decisões - políticas, administrativas e financeiras - serão tomadas de forma soberana nas suas instâncias de deliberação; II) A CSP-CONLUTAS não é apolítica, podendo posicionar-se sobre os acontecimentos políticos na sociedade; III) A CSP-CONLUTAS valorizará e receberá de bom grado, em suas 
instâncias, todos os trabalhadores e trabalhadoras filiados/filiadas ou não a partidos políticos.

Parágrafo quinto - A democracia e a unidade na ação.

I) A CSP-CONLUTAS pautará o seu funcionamento por formas e processos que assegurem a democracia, um rico e saudável debate interno, o respeito à diversidade política existente em seu interior, com o objetivo de assegurar a sua unidade na ação. II) Os processos de decisões de suas políticas devem basear-se em ampla participação das entidades e organizações a ela filiadas.

Parágrafo sexto - A autonomia das entidades de base filiadas. I) Todas as entidades filiadas (sindicais, movimentos, oposições e minorias) filiadas gozam de autonomia política, organizativa e financeira em relação a Central.

Parágrafo sétimo - A solidariedade internacional entre os trabalhadores e trabalhadoras. I) A solidariedade internacional e a unidade dos trabalhadores e trabalhadoras e das suas organizações de classe de todas as regiões do mundo, para a defesa dos seus direitos e interesses, são valores permanentes buscados pela Central; II) A libertação da classe trabalhadora de toda forma de opressão e exploração que ela sofre no mundo em que vivemos, é uma tarefa que não se inscreve apenas nos marcos de um país e, sim, deve ser tomada no plano internacional.

\section{Capítulo IV. Da filiação/admissão, da desfiliação, dos direitos e deveres dos associados}

Artigo $6^{\circ}$ - Poderão filiar-se à Central as entidades sindicais, oposições e minorias sindicais, organizações de trabalhadores desempregados e desempregadas, de aposentados e aposentadas, movimentos populares urbanos e rurais, organizações do movimento estudantil e movimentos de luta contra as opressões, que serão tratados neste Estatuto pelas expressões "associado(s)" e "filiado(s)".

Parágrafo primeiro - A filiação de entidades e movimentos será efetivada mediante requerimento escrito encaminhado à Secretaria 
Executiva Nacional, que deve estar acompanhado de documentos comprobatórios de que o pedido de filiação foi aprovado pelas instâncias deliberativas correspondentes da entidade, movimento ou organização pleiteante.

Parágrafo segundo - À Coordenação Nacional compete analisar e aceitar, ou não, os pedidos de filiação apresentados à Central, cabendo recurso ao Congresso Nacional.

Parágrafo terceiro - As oposições sindicais e minorias sindicais de entidades ligadas às outras centrais poderão participar da CSP-CONLUTAS e de suas instâncias, podendo inclusive eleger delegados e delegadas aos Congressos, mediante credenciamento junto à Coordenação respectiva que, por sua vez, poderá aceitar, ou não, o referido credenciamento.

Parágrafo quarto - A oposição sindical somente será cadastrada caso esteja de acordo com as regras, objetivos e princípios contidos no presente Estatuto Social.

Parágrafo quinto - As entidades sindicais, oposições e minorias, organizações de trabalhadores desempregados e desempregadas, movimentos populares urbanos e rurais, organizações de aposentados e aposentadas, organizações do movimento estudantil e movimentos de luta contra a opressão e outros, ao filiarem-se, preservarão a sua autonomia política, administrativa e financeira em relação a Central.

Parágrafo sexto - Nenhum associado responde, subsidiária ou solidariamente, pelos atos da entidade.

Parágrafo sétimo - A desfiliação de entidades e movimentos será efetivada mediante requerimento escrito encaminhado à Secretaria Executiva Nacional da Central, acompanhado de documentos comprobatórios de que o pedido de desfiliação foi aprovado pelas instâncias deliberativas correspondentes da entidade, movimento ou organização pleiteante.

Parágrafo oitavo - A Secretaria Executiva Nacional compete analisar o pedido, solicitar novos documentos, se for o caso, e encaminhá-lo à Coordenação Nacional que poderá aceitar, ou não, o pedido, cabendo ainda recurso ao Congresso Nacional. 
Artigo $7^{\circ}$ - São direitos das entidades filiadas à CSP- CONLUTAS: I) Participar das suas diversas instâncias de Coordenação, com direito a voz e a voto, nos termos do presente Estatuto Social. II) Eleger delegados e delegadas para participar do Congresso Nacional, do Congresso de seu Estado ou Região, de representantes à Coordenação Nacional, desde que estejam em dia com suas obrigações financeiras.

\section{Capítulo V. Da estrutura, organização, funcionamento e administração}

Artigo $8^{\circ}$ - São instâncias de organização, de funcionamento e deliberação da CSP-CONLUTAS, na seguinte ordem hierárquica: I) Congresso Nacional; II) Coordenação Nacional;

III) Secretaria Executiva Nacional; IV) Coordenação Estadual ou Regional; V) Secretaria Executiva Estadual ou Regional.

Parágrafo Único - Nos âmbitos nacional, estadual e Regional serão eleitos, também, juntamente com as Secretarias Executivas, os Conselhos Fiscais respectivos.

\section{Capítulo VI. Do Congresso Nacional}

Artigo $9^{\circ}$ - O Congresso Nacional é a instância máxima de decisão da CSP-CONLUTAS e será realizado, ordinariamente, a cada 02 (dois) anos.

Parágrafo Primeiro - O Congresso Nacional será composto por delegados e delegadas eleitos/eleitas por todas as entidades sindicais, movimentos populares urbanos e rurais, organizações de trabalhadoras e trabalhadores desempregados e de aposentados e aposentadas.

Parágrafo segundo - A participação das entidades estudantis e dos movimentos de luta contra as opressões não poderá exceder o percentual de $5 \%$ do total dos delegados inscritos ao Congresso Nacional.

Parágrafo terceiro - A convocação do Congresso Nacional cabe à Coordenação Nacional e se fará da seguinte forma: I) Pelo menos 4 (quatro) meses antes da realização do Congresso deve ser publicada, no veículo oficial de comunicação da Central, a data e a pauta do 
Congresso; II) O local de realização do Congresso deve ser divulgado com antecedência mínima de 3 (três) meses; III) Compete à Coordenação Nacional definir os critérios em base aos quais se elegerão os delegados e delegadas, bem como as demais normas que nortearão a organização do Congresso.

Artigo $10^{\circ}$ - Compete ao Congresso Nacional decidir soberanamente sobre todo e qualquer ponto colocado em pauta.

Parágrafo primeiro - Caso a convocação do Congresso Nacional não seja feita no período previsto neste Estatuto pela Coordenação Nacional, a convocação poderá ser feita por 1/5 das entidades e movimentos filiados e em dia com suas obrigações estatutárias.

Parágrafo segundo - O quorum para deliberação das modificações estatutárias é de $2 / 3$ (dois terços) dos delegados e delegadas com direito a voto nesta instância.

\section{Capítulo VII. Da coordenação nacional}

Artigo 11 - A Coordenação Nacional corresponde à Assembleia Geral da entidade, e é o órgão de direção cotidiana da Central entre seus congressos nacionais.

Artigo 12 - A Coordenação Nacional reunir-se-á, ordinariamente, a cada 2 (dois) meses, ou extraordinariamente conforme necessidade, mediante convocação a cargo da Secretaria Executiva Nacional da Central.

Parágrafo primeiro - A convocação deverá ser publicada pelo menos 30 (trinta) dias antes da realização da Coordenação Nacional, no veículo oficial de comunicação da Central, contendo a data da reunião.

Parágrafo segundo - O local de realização da Coordenação Nacional e pauta devem ser divulgados com antecedência mínima de 15 (quinze) dias.

Parágrafo terceiro - Caso a Secretaria Executiva Nacional não convoque a Coordenação Nacional no período previsto neste Estatuto, 
a convocação poderá ser feita por 1/10 das entidades e movimentos filiados à Central em dia com suas obrigações estatutárias.

Artigo 13 - A Coordenação Nacional será composta por representantes eleitos/eleitas nas instâncias das entidades e movimentos filiados à CSP-CONLUTAS, em dia com as suas contribuições financeiras à Central, nas seguintes proporções:

I) Entidades sindicais: Com até 4.999 trabalhadores na base: 1 voto; De5.000 a 19.999 na base: 02 votos; De20.000 a 39.999 na base: 03 votos; De40.000 a 79.999 na base: 04 votos; De 80.000 trabalhadores na base, em diante: 05 votos, mais1 a cada 20.000 ou fração de 10.000, limitado a 10 votos.

I.a) A base das oposições sindicais e das minorias das entidades sindicais não filiadas à Central deve ser definida a partir do percentual da categoria que representarem.

I.b) Para as oposições sindicais deve se levar em conta o número de votos obtidos na última eleição e, no caso das minorias, a proporção que representam na diretoria da entidade. II) Movimentos populares:

II.a) Acampamentos e ocupações (urbanos ou rurais): Até 500 famílias: 1 voto; De 501 a 1.000: 2 votos; de 1.001 a 2000 famílias: 3 votos; acima de 2.000 famílias: 1 voto a cada 1.000 .

II. b) Núcleos Comunitários: Até 125 famílias em assembleia: 1 voto; de 126 a 250 famílias representadas em assembleia: 2 votos; de 251 a 500 famílias representadas em assembleia: 3 votos; acima de 500 famílias representadas em assembleia: 1 voto a cada 250 famílias.

III) Movimentos populares sem base de representação definida: 1 voto por entidade.

Parágrafo primeiro - Para cada reunião da Coordenação Nacional as entidades e movimentos indicarão seus representantes eleitos para compô-la, de acordo com o regimento interno de cada entidade.

Parágrafo segundo - A participação das entidades estudantis e dos movimentos de luta contra as opressões não poderá exceder o percentual de $5 \%$ do total de inscritos com direito a voto para participação na 
Coordenação Nacional, devendo as representações desses segmentos reunirem-se para indicação dos representantes com direito a voto.

\section{Capítulo VIII. Da secretaria executiva nacional.}

Artigo 14 - A Secretaria Executiva Nacional é o órgão executivo da Coordenação Nacional de entidades de base filiadas, e terá como atribuição fundamental implementar as resoluções aprovadas na Coordenação no intervalo entre as suas reuniões.

Parágrafo único - A Secretaria Executiva Nacional será escolhida na primeira reunião da Coordenação Nacional da entidade realizada após o Congresso ordinário, em base ao critério da proporcionalidade direta e qualificada dos votos obtidos pelas chapas concorrentes, se houver mais de uma. Artigo 15 - A Secretaria Executiva Nacional será composta por 27 (vinte e sete) membros efetivos e 8 (oito) membros suplentes.

Parágrafo único - Na composição dos membros da Secretaria deve-se aplicar a cota de gênero de no mínimo 30\%, como forma de ampliar a participação feminina.

Artigo 16 - A Secretaria terá ainda a atribuição de convocar as reuniões da Coordenação Nacional.

Artigo 17 - A representação política da entidade poderá ser exercida por qualquer dos membros da Secretaria Executiva Nacional ou ainda por pessoa indicada pela Secretaria, respeitadas as deliberações das instâncias da entidade.

Artigo 18 - A representação legal, judicial e/ou administrativa será designada pela Secretaria Executiva, podendo ser modificada pela Coordenação Nacional.

Artigo 19 - O mandato dos membros da Secretaria Executiva Nacional é de dois anos, revogável pela Coordenação Nacional ou pela entidade (ou base) a qual pertença o representante, a qualquer momento que esta julgar necessário, nos termos do Estatuto.

Parágrafo único - A revogabilidade do mandato de membros da Secretaria Executiva Nacional apóia-se no princípio de que o mandato não 
pertence à pessoa que o exerce nem ao organismo de direção a que ele pertença. $\mathrm{O}$ mandato pertence à base da entidade que ele representa.

Artigo 20 - O mandato do membro da Secretaria Executiva Nacional poderá ser revogado nas seguintes situações: I) A pedido da entidade ou da base a que pertença o membro da Secretaria, entendida, no segundo caso, a representação de uma minoria ou oposição sindical, cabendo tão somente ao setor de base a que este membro representa pedir a sua substituição; II) Por ruptura com o Programa e Princípios da Central; III) Por boicote deliberado no encaminhamento das resoluções aprovadas pelo Congresso ou pela Coordenação Nacional; IV) Por falta moral grave.

Parágrafo primeiro - Em todos os casos será garantido amplo direito de defesa ao membro que se propõe substituir.

Parágrafo segundo - Nos casos das alíneas II e III a decisão poderá se tomada pela maioria simples dos votantes na Coordenação Nacional.

Parágrafo terceiro - No caso da alínea IV a Coordenação Nacional terá que observar o quórum mínimo de $50 \%$ mais um das entidades com direito à representação na Coordenação Nacional, e o voto de 2/3 dos presentes.

Parágrafo quarto - A Coordenação Nacional poderá ainda adotar outras formas de punição, mais brandas, antes de aprovar a revogação do mandato do membro da Secretaria.

Parágrafo quinto - Em nenhuma hipótese poderá ocorrer a revogação do mandato em função de diferenças políticas.

Artigo 21 - No caso de renúncia do membro da Secretaria Executiva Nacional, não havendo oposição da base a qual representa, a substituição poderá ser feita por suplente ou pela chapa pela qual foi eleito para a Secretaria.

\section{Capítulo IX. Do conselho fiscal}

Artigo 22 - O Conselho Fiscal será composto por 3 (três) membros efetivos e 3 (três) suplentes, que terão a responsabilidade de fiscalizar as contas da Central. 
Parágrafo primeiro - O Conselho Fiscal será escolhido na primeira reunião da Coordenação Nacional da entidade realizada após o Congresso ordinário. Se houver mais candidatos propostos do que o número de membros efetivos e suplentes do Conselho, a votação será individual, observando-se a ordem de votação dos eleitos para a composição do órgão.

Parágrafo segundo - O Parecer do Conselho Fiscal será apresentado anualmente à Coordenação Nacional, no primeiro quadrimestre do exercício seguinte, devendo ser subscrito por no mínimo 2/3 (dois terços) dos seus membros efetivos.

Parágrafo terceiro - O mandato do Conselho Fiscal será de dois (2) anos, podendo ser revogado nas mesmas situações e condições previstas para a revogabilidade dos membros da Secretaria Executiva Nacional.

Parágrafo quarto - Poderão compor o Conselho Fiscal quaisquer membros das entidades filiadas, excetuando-se aquelas entidades cujos representantes ocupem cargo na Comissão de Finanças da Secretaria Executiva Nacional.

\section{Capítulo X. Das Disposições Relativas Á Composição Das Secretarias Executivas Estaduais, Secretarias Executivas Regionais E Respectivos Conselhos Fiscais Estaduais E Regionais}

Artigo 23 - As Coordenações estaduais e regionais, Secretarias Executivas respectivas e Conselhos Fiscais serão constituídas pela representação das entidades e movimentos que fazem parte da Central no Estado ou região, cabendo a definição do número de membros de cada Secretaria Executiva (efetivos e suplentes) ser definida pela própria Coordenação de cada Estado ou região, não podendo exceder o número de membros da Secretaria Executiva Nacional.

Artigo 24 - Aplicam-se às coordenações estaduais e regionais, secretarias executivas estaduais e regionais e respectivos conselhos fiscais os dispositivos relativos às instâncias nacionais da entidade, constantes dos artigos 11 a 13 (para as coordenações estaduais e 
regionais), 14 a 21 (para as secretarias executivas estaduais e regionais) e do artigo 22 (para os conselhos fiscais nos estados e regiões).

Parágrafo único - $\mathrm{O}$ registro em cartório das secretarias executivas estaduais e regionais e dos conselhos fiscais respectivos, para efeitos legais, será encaminhado por ato de nomeação da Coordenação Nacional da entidade, observando sempre a composição apontada no estado ou região.

Artigo 25 - Nenhum membro de qualquer instância da entidade responderá, pessoal ou solidariamente, por perdas ou danos porventura causados pela entidade.

\section{Capítulo XI. Da sustentaçao financeira}

Artigo 26 - A sustentação financeira da CSP-CONLUTAS será feita por dois meios de arrecadação:

Parágrafo primeiro - Uma contribuição regular, paga mensalmente pelas entidades e movimentos, para a manutenção da entidade.

Parágrafo segundo - Por rateio de despesas, sempre e quando necessário, para cobrir gastos extraordinários, referentes a atividades gerais.

Parágrafo terceiro - A não participação de uma entidade neste rateio não será impeditivo para que ela participe com direito pleno de voto nas instâncias da Central.

Artigo 27 - A contribuição mensal deverá ser paga pelas entidades e movimentos na seguinte forma:

Parágrafo primeiro - Entidades com personalidade jurídica e arrecadação regular (sindicatos, federações, confederações, associações de classe, entre outras), pagarão mensalidade à CSP-CONLUTAS correspondente a $5 \%$ (cinco por cento) da arrecadação global mensal.

Parágrafo segundo - Entidades com personalidade jurídica e sem arrecadação regular e/ou entidades sem personalidade jurídica e com arrecadação irregular (movimentos, comitês, entre outras) pagarão uma anuidade no valor equivalente a meio salário mínimo; 
Parágrafo terceiro - Oposições sindicais e minorias sindicais reconhecidas pagarão uma anuidade no valor equivalente a um salário mínimo.

Artigo 28 - A CSP-CONLUTAS não poderá receber recursos oriundos da União, Estados, Municípios, ONGs ou de empresas.

Parágrafo primeiro - A CSP-CONLUTAS poderá receber recursos de convênios nacionais e internacionais para financiamento de atividades que realize, apenas e tão somente quando a fonte destes recursos for uma organização ou entidade de trabalhadores e trabalhadoras e a utilização destes recursos não interferir, por qualquer forma que seja, na soberania de decisão das suas instâncias.

Parágrafo segundo - A CSP-CONLUTAS não poderá desenvolver atividades comerciais ou financeiras, excetuando-se a confecção e venda de materiais e artigos promocionais da própria Central (publicações, camisetas, broches e similares) ou das campanhas de luta que estiver promovendo, assim como as iniciativas de autosustentação dos movimentos sindicais e populares, que ficam permitidas, desde que aprovadas nas instâncias da Central.

Parágrafo terceiro - No caso de contribuições compulsórias depositadas na conta da Central, estes valores serão devolvidos aos sindicatos de base que darão a elas a destinação que suas instâncias aprovarem.

Artigo 29 - O valor arrecadado com as contribuições regulares pagas à CSP-CONLUTAS pelas entidades e movimentos será distribuído por toda a sua estrutura organizativa na seguinte proporção: a CSP-CONLUTAS Nacional fica com o corresponde a $40 \%$ (quarenta por cento) e as instâncias estaduais e regionais ficam com 50\% (cinquenta por cento) do valor arrecadado e os outros $10 \%$ constituirão um fundo de lutas da Central, que receberá o repasse automático deste percentual das contribuições recebidas.

Parágrafo único - O recolhimento da contribuição será feito centralizadamente junto a uma conta bancária da instância nacional da Central, que efetuará o repasse a cada instância estadual e/ou regional.

Artigo 30 - A contribuição de cada entidade relativa ao rateio para o financiamento das campanhas e atividades extraordinárias da Central, 
será definida pela instância de Coordenação que estiver promovendo a campanha/atividade, sempre com base em critérios que respeitem, proporcionalmente, a capacidade financeira de cada entidade e movimento.

\section{Capítulo XII. Do patrimônio}

Artigo 31 - O patrimônio da CSP-CONLUTAS será constituído de bens móveis e imóveis, legados, doações, veículos, ações e apólices de dívida pública bem como de todo e qualquer bem ou haver da Coordenação Nacional.

\section{Capítulo XIII. DA Dissolução Da Entidade}

Artigo 32 - A Central somente será dissolvida por decisão de no mínimo $3 / 4$ (três quartos) dos seus associados em Congresso Nacional especialmente convocado para este fim.

Artigo 33 - Os casos omissos serão analisados e decididos pela Coordenação Nacional da Central, ad referendum do Congresso, sempre que esta julgar necessário.

\section{Capítulo XIV. Das disposições transitórias}

Artigo 34 - As disposições constantes dos artigos $8 .^{\circ}$ e 24 , relativas à organização das instâncias estaduais e regionais da entidade, terão um prazo para implementação de dois anos, devendo ser acompanhadas pela Secretaria Executiva Nacional.

Artigo 35 - A Coordenação Nacional deverá debater e deliberar sobre a instituição de uma comissão permanente para cuidar dos assuntos relativos à acessibilidade e mobilidade dos trabalhadores e trabaIhadoras portadores de necessidades especiais.

Artigo 36 - A Coordenação Nacional da entidade deverá debater e deliberar sobre a instituição de uma Secretaria de Formação, que englobe as instâncias nacional, estaduais e regionais e de um instituto de formação próprio para assessorar as entidades de base. 
Artigo 37 - A Coordenação Nacional deverá instituir um fundo permanente de apoio aos movimentos populares, autorizando o repasse de recursos regulares da Central para este fundo, definindo o volume de recursos e a forma como esses recursos serão aplicados nas atividades dos diversos movimentos populares que fazem parte da Central.

Parágrafo primeiro - A proposta de regulamentação deverá ser submetida à primeira reunião da Coordenação Nacional ocorrida após o Congresso.

Artigo 38 - À Coordenação Nacional caberá analisar, à luz da realidade política e do processo de reorganização da classe trabalhadora, podendo decidir pela antecipação ou, excepcionalmente, pelo adiamento da data do próximo Congresso ordinário da entidade.

Direção

A Secretaria Executiva Nacional e o Conselho Fiscal da CSP-Conlutas, foram eleitos na primeira reunião da Coordenação Nacional, ocorrida nos dias 13, 14 e 15 de julho de 2012, no Rio de Janeiro. Três vagas ficaram destinadas para a posterior indicação do MTST. Segue abaixo a relação em ordem alfabética:

\section{SECRETARIA EXECUTIVA NACIONAL}

Altino de Melo Prazeres (Sindicato dos Metroviários de SP)

Atnágoras Teixeira Lopes

(Sindicato dos Trab. Construção Civil de Belém/PA)

Beatriz Paiva de Oliveira (Sindicato dos Bancários/RN)

Camila Ribeiro Duarte Lisboa (Movimento Mulheres em Luta)

Clara Gomide Saraiva/Tamiris Pereira Rizzo (ANEL - Assemb. Nacional dos Estudantes - Livre)

Cláudio Luiz Alves de Santana (Oposição Alternativa na APEOESP/SP) Dirceu Travesso/ Wilson Aparecido Ribeiro (Oposição Bancária SP) Eliana Moreira de Lacerda (Federação Nacional dos Gráficos) 
Gilberto Antonio Gomes

(Federação Sindical e Democrática dos Metalúrgicos/MG)

Joaninha de Oliveira Johnson (SINTE/SC)

João Batista da Fonseca

(MTL - Movimento Terra Trabalho e Liberdade)

José Batista Neto

(Sindicato dos Trabalhadores da Construção Civil de Fortaleza/CE)

José Maria de Almeida

(Federação Sindical e Democrática dos Metalúrgicos/MG)

Júlio César Condaque

(Movimento Nacional Quilombo Raça e Classe)

Luis Carlos Prates - Mancha

(Sind. dos Metalúrgicos de S. José dos Campos/SP)

Magno de Carvalho Costa (SINTUSP/SP)

Manoel Crispim Clemente Flores/Júlio César T. Pereira (SINDSPREV/RJ)

Maria da Conceição de Oliveira Silva (SIND-REDE-BH/MG)

Marinalva Silva Oliveira (ANDES-SN)

Mário Sérgio Martins/ Gualberto Isaias de Oliveira Tinoco - Pitéu (SEPE/RJ)

Mauro Ailton Puerro (SINPRO - Guarulhos/SP)

Miguel Leme Ferreira (Oposição Alternativa na APEOESP/SP)

Neida Porfírio de Oliveira/ Terezinha Bullé da Silva (CPERS-Sindicato/RS)

Paulo Arletes Rios Barela (Oposição ASSIBGE)

Paulo Marcos Borges Rizzo (ANDES-SN)

Saulo Costa Arcangeli (SINTRAJUFE/MA)

Sebastião Carlos Pereira Filho - Cacau (Oposição Bancária BH/MG) 
Valdir Martins de Souza

(MUST - Movimento Urbano Sem Teto)

Vânia Carvalho Pinheiro (SINDEESS-BH/MG)

Vera Justina Guasso (SINDPPD/RS)

William do Nascimento Carvalho/ David Moreno Montenegro (SINASEFE)

Yuri Monteiro Aguiar (SINTECT/RS)

\section{CONSELHO FISCAL:}

Herbert Claros da Silva

(Sind. dos Metalúrgicos de S. José dos Campos/SP)

Josevaldo Pessoa da Cunha

(ANDES-SN)

Marcos de Macedo Tinoco

(Sindicato dos Bancários/RN)

Marcos Roberto Ferreira de Azevedo

(Sindicato dos Comerciários de Santa Cruz do Sul)

Maria de Santana Costa

(Sind. Trab. na Confecção Feminina Fortaleza/CE)

Telmo de Oliveira

(Sindicato dos Comerciários de Nova Iguaçu/RJ) 